\title{
Working
}

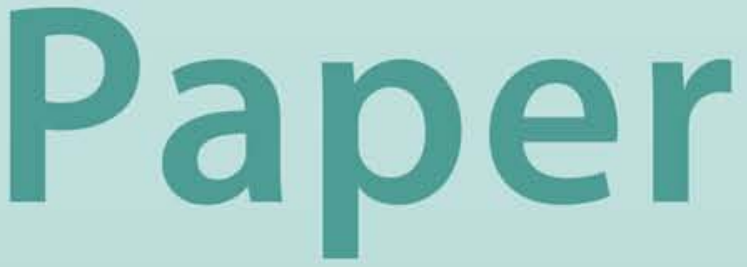




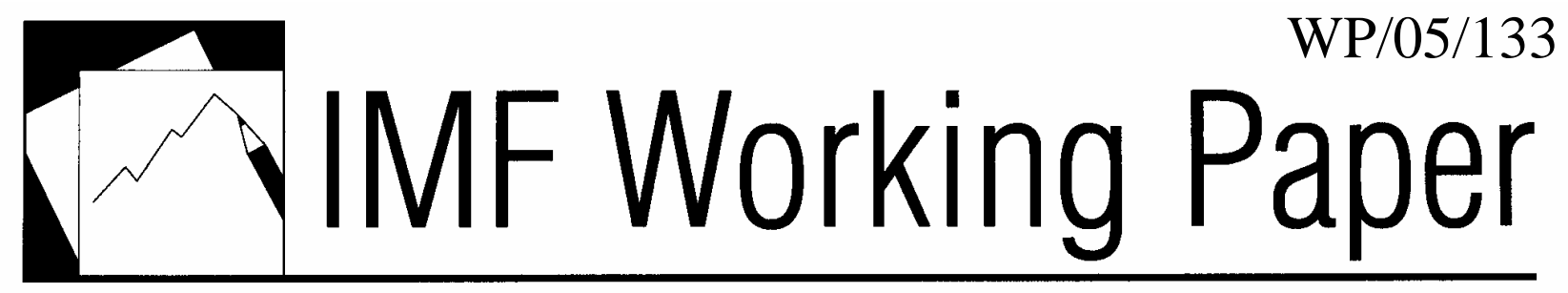

Slovakia’s 2004 Tax and Welfare Reforms

David Moore 


\title{
IMF Working Paper
}

European Department

\section{Slovakia's 2004 Tax and Welfare Reforms}

\author{
Prepared by David Moore ${ }^{1}$ \\ Authorized for distribution by Juan José Fernández-Ansola
}

July 2005

\begin{abstract}

\section{This Working Paper should not be reported as representing the views of the IMF.} The views expressed in this Working Paper are those of the author(s) and do not necessarily represent those of the IMF or IMF policy. Working Papers describe research in progress by the author(s) and are published to elicit comments and to further debate.
\end{abstract}

The paper reviews Slovakia's comprehensive reforms to its taxation and welfare systems in 2004, including the introduction of a flat-rate income tax and single-rate value-added tax (VAT), and linkage of social benefits to participation in labor market programs. Though revenues following the reform are lower as a ratio to GDP, the paper argues that the reforms have helped encourage investment and improved efficiency by broadening the tax base, reducing the administrative burden, and improving work incentives. The paper also looks at some implications of the reforms for income distribution and social protection.

JEL Classification Numbers: H20, H53, I38, E62

Keywords: tax reform, welfare reform, Slovakia

Author(s) E-Mail Address: dmoore@imf.org

\footnotetext{
${ }^{1}$ The author would like to thank, without implicating, Mark de Broeck, Nada Choueiri, Costas Christou, Stephan Danninger, Juan Jose Fernández-Ansola, Nienke Oomes, and István Székely for useful comments and suggestions. The author is also indebted to Ludovít Ódor, Branislav Durajka, Michal Horváth, and Jaroslav Kováč for most helpful discussions. Parts of the paper, notably on the composite marginal tax rate in Section IV, and the distributional impact of indirect taxes in Section V, draw on unpublished work by the late John King.
} 
Contents

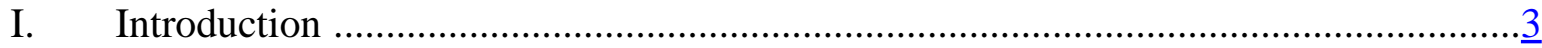

II. Brief Overview of the Reforms ..................................................................... 4

III. Fiscal Effects of the Reforms: First Results ...................................................... $\frac{8}{2}$

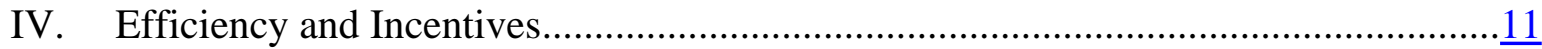

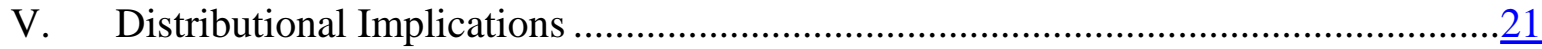

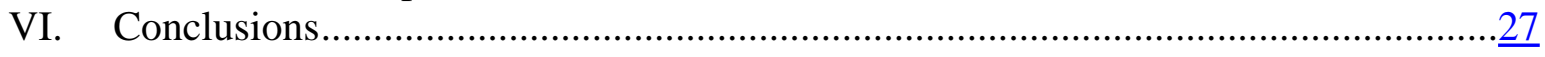

Box

1. IMF Recommendations on Tax System Design ..............................................

Figures

1. Slovak Republic: Effective Marginal Income Tax Rate, Single Taxpayer.................. $\underline{5}$

2. Slovak Republic: Effective Marginal Income Tax Rate, Married Taxpayer (with non-working spouse and two children) ..................................................... 6

3. Slovak Republic: Labor Income and Net Income, 2003-04 ...................................

4. Slovak Republic: Tax Structure ....................................................................... $\frac{8}{8}$

5. Slovak Republic: Tax Structure, including Social Contributions ............................10

6. Slovak Republic: State Benefits and Social Assistance.....................................11

7. Composite Marginal Tax Rate, Single Taxpayer...............................................15

8. Composite Marginal Tax Rate, Married Taxpayer (with non-working spouse and two children) ........................................................................ 15

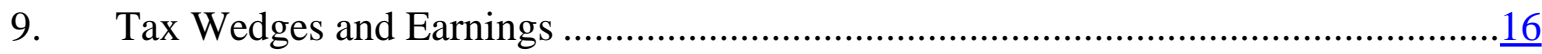

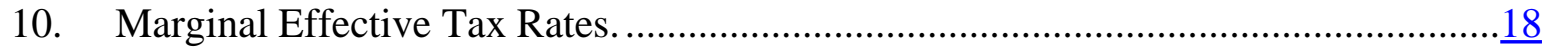

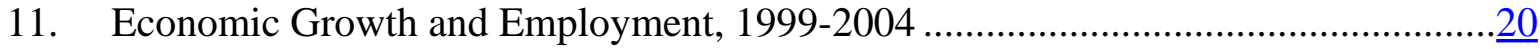

12. Corporate Income Tax Rates, 1995-2004 …..................................................... $\frac{21}{22}$

13. Average Personal Income Tax Rate ................................................................. 22

14. VAT Burden and the Income Distribution ..................................................... $\frac{23}{23}$

15. Excise Tax Burden and the Income Distribution.............................................

16. Average Composite Tax Rate ..................................................................24

17. Average Composite Tax Rate, Excluding Non-Health SSCs ................................25

Tables

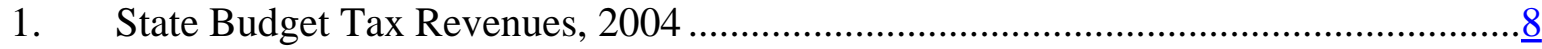

2. Estimated Impact of the 2004 Tax Reform ...................................................... 9

3. Social Contribution Rates .....................................................................

4. The Subsistence Minimum ........................................................................... $\underline{26}$

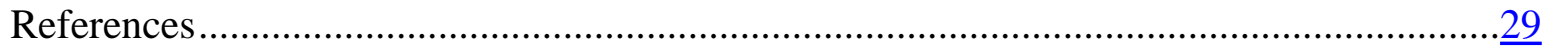

Appendix I. Background Information on the Reforms ........................................... 


\section{INTRODUCTION}

This paper reviews Slovakia's recent reforms to its tax and welfare systems. These reforms are part of a wide-ranging agenda that also includes reforms to pensions, healthcare, the labor market, and the legal system, with further reforms planned in the education system. ${ }^{2}$ The focus on the tax and welfare reforms has two motivations. First, these reforms are important in their own right. Second, the potential for interaction between tax and welfare systems can have strong implications for incentives to work-especially important in a context of high unemployment, which remains one of Slovakia's most pressing economic and social problems.

The flat-rate income tax, which featured prominently in the reforms, has become a particular topic of interest for policymakers in the region. ${ }^{3}$ Estonia introduced a flat-rate income tax in 1995, and was followed by several other countries from the former Soviet Union-notably including Russia, which introduced a 13 percent tax in 2001. More recently, Poland has been considering introducing a flat-rate income tax, and the Romanian government elected in late 2004 moved swiftly to introduce a 16 percent flat tax effective from January 2005.

The reforms have been undertaken in a context of a need for medium-term fiscal consolidation. The Slovak government plans to meet the Maastricht fiscal deficit criterionthe ceiling of 3 percent of GDP_-by 2007. The fiscal deficit was between 3 and 4 percent of GDP in both 2003 and 2004; and the task of reducing the deficit below 3 percent in the period ahead is being complicated by additional pressures from the costs associated with EU accession and the introduction of a second pillar to the pension system. In the context of the government's medium-term goals, the tax reform was designed as broadly revenue-neutral, and welfare reform had to be carried out within a tight expenditure envelope.

The paper is set out as follows. Section II briefly outlines the tax and welfare reforms introduced in 2004. Section III examines the available evidence on the fiscal implications of the reforms. Section IV looks at the efficiency implications of the reforms, in particular for incentives to work and invest. Section V notes some of the distributional implications of tax reform and the available evidence on the effectiveness of the welfare system in its social protection role. Section VI concludes.

${ }^{2}$ See IMF (2005).

3 See for example Ivanova, Keen, and Klemm (2005). 


\section{BRIEF OVERVIEW OF THE REFORMS ${ }^{4}$}

The goal of the 2004 tax reform was a competitive tax system. According to the Slovak Ministry of Finance (2003a, 2003b), the reform aims to improve the efficiency, transparency, simplicity, and fairness of the tax system, based on the following principles:

- broad revenue neutrality, with a shift in the tax burden from direct to indirect taxes;

- low standard tax rates, financed by eliminating special treatments and exemptions;

- minimizing distortions in the economy from taxes used for "non-fiscal" goals; and

- minimizing double taxation of income.

The "19 percent" tax reform greatly simplifies the tax system.

- The reformed personal income tax features a single rate of 19 percent and a high taxfree threshold (Figures 1 and 2). It replaces 21 different tax rates, including a fiveband rate structure on wage income that ranged from 10 to 38 percent, and withholding tax rates on capital income ranging from 5 to 25 percent.

- The corporate income tax rate has also been reduced to 19 percent, and dividend taxation has been abolished.

- Most income tax exemptions have been cancelled, notably tax holidays for newly established firms; future investment incentives must comply with EU state aid rules.

- The single value-added tax (VAT) rate of 19 percent replaces dual VAT rates of 14 and 20 percent.

- Excise taxes were increased and aligned with EU requirements.

- Several smaller taxes were abolished.

- A separate reform modestly reduced overall social contribution rates by 2.4 percentage points and increased the ceilings for pension and unemployment insurance contributions.

In general, the tax reform conforms to core IMF recommendations on tax system design (Box 1).

The goal of the welfare reform was to promote employment, by addressing benefit dependency and disincentives to work. Social assistance benefits are paid to individuals and families with incomes below the national poverty line, the "subsistence minimum" (see Section IV). Benefits had been high relative to wages, contributing to a high benefit

\footnotetext{
4 Appendix I provides additional background information on the reforms.
} 
dependency rate: the OECD (2002) observed that for a family with two children, welfare payments could exceed the net average wage.

\section{Box 1. IMF Recommendations on Tax System Design ${ }^{1}$}

"The IMF has provided input into the design of tax reforms in many transition and developing countries, and generally recommended that tax systems have the following characteristics:

- Heavy reliance on broadly-based sales taxes, such as VAT, preferably with a single rate and minimal exemptions, and excise taxes levied on petroleum products, alcohol, tobacco and a few items that are considered luxuries.

- No reliance on exports duties, which inhibit international competition, or on small nuisance taxes, administration of which is not effective.

- Import taxation at as low levels as possible, with a limited dispersion of rates to minimize effective rates of protection.

- An administratively simple form of personal income tax, with limited deductions, a moderate top marginal rate, an exemption limit large enough to exclude persons with modest incomes, and a substantial reliance on withholding.

- A corporate income tax levied at only one moderate-to-low rate aligned with the top personal income tax rate, with depreciation and other non-cash expenditure provisions uniform across sectors and minimal recourse to sector or activity-specific incentive schemes."

\footnotetext{
${ }^{1}$ Reprinted from Stepanyan (2003).
}

Figure 1. Slovak Republic: Effective Marginal Income Tax Rate, Single Taxpayer

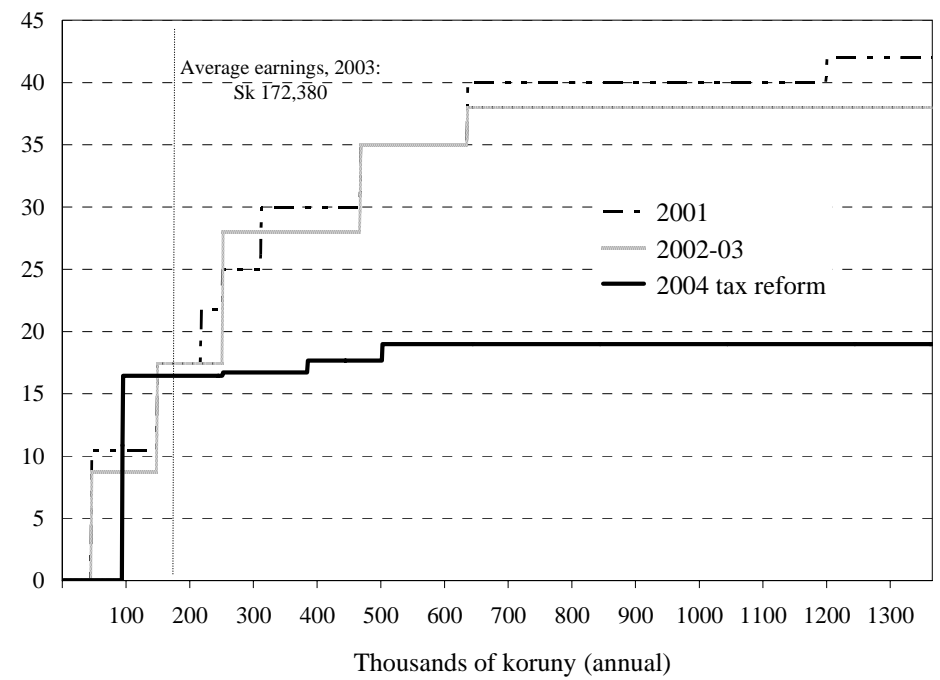

Sources: Slovak Ministry of Finance and IMF staff calculations. For 2004, the multiple marginal effective tax rates reflect the income tax deductibility of social contributions, which are subject to different ceilings by type. 
Figure 2. Slovak Republic: Effective Marginal Income Tax Rate, Married Taxpayer (with non-working spouse and two children)

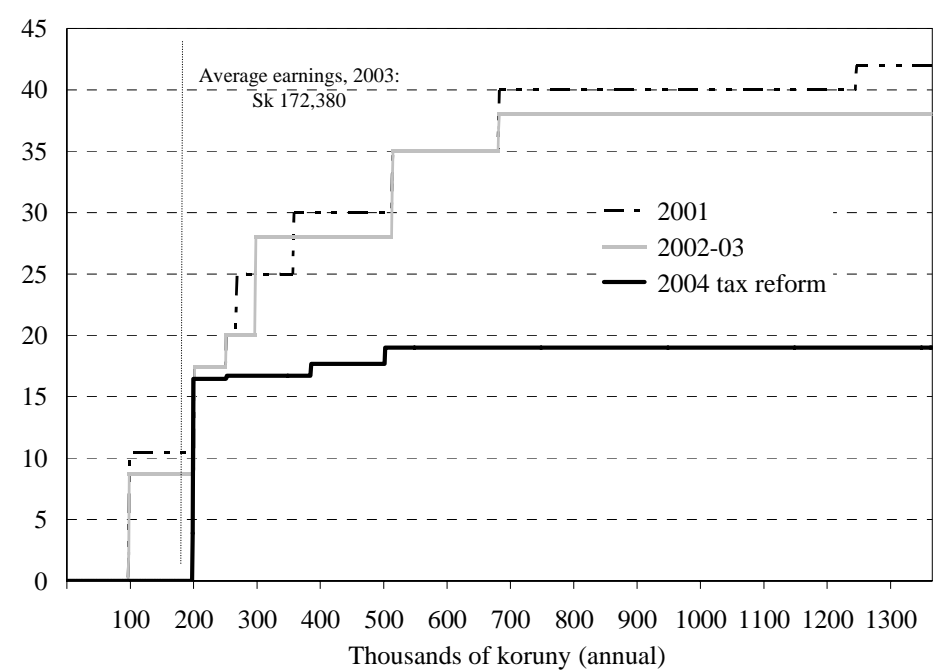

Sources: Slovak Ministry of Finance and IMF staff calculations. For 2004, the multiple marginal effective tax rates reflect the income tax deductibility of social contributions, which are subject to different ceilings by type.

The reform introduced an "activation program" by restructuring the benefit formula to depend on work effort. The reform significantly reduced the basic benefit but introduced an "activation allowance" for which recipients are required to demonstrate effort to improve their situation, for example by participating in community volunteer work or retraining programs.

Social assistance benefits are now reduced less abruptly if the recipient earns labor income. The previous social assistance scheme was a simple top-up of income to the benefit level; any additional earnings resulted in a correspondingly lower benefit. In the new scheme, several types of income are deemed exempt in the calculation of the social assistance benefit, including 25 percent of individual income from dependent services.

The welfare reform has had different implications for different-size families. Figure 3 presents Slovak Ministry of Labor (2004) estimates of the impact of the reform for differentsize families, assuming participation in activation programs and taking account of the taxwelfare interactions from earning labor income. ${ }^{5}$ Assuming participation in activation programs, smaller families can maintain benefit levels near the pre-reform levels, even increasing their household income if they earn the minimum wage. However, for families with four or more children, benefit reductions are greater.

5 These calculations do not include unemployment benefits, which are not available to the long-term unemployed. The graphs are in nominal koruny; average CPI inflation in 2004 was 7.5 percent. 
Figure 3. Slovak Republic: Labor Income and Net Income, 2003-04
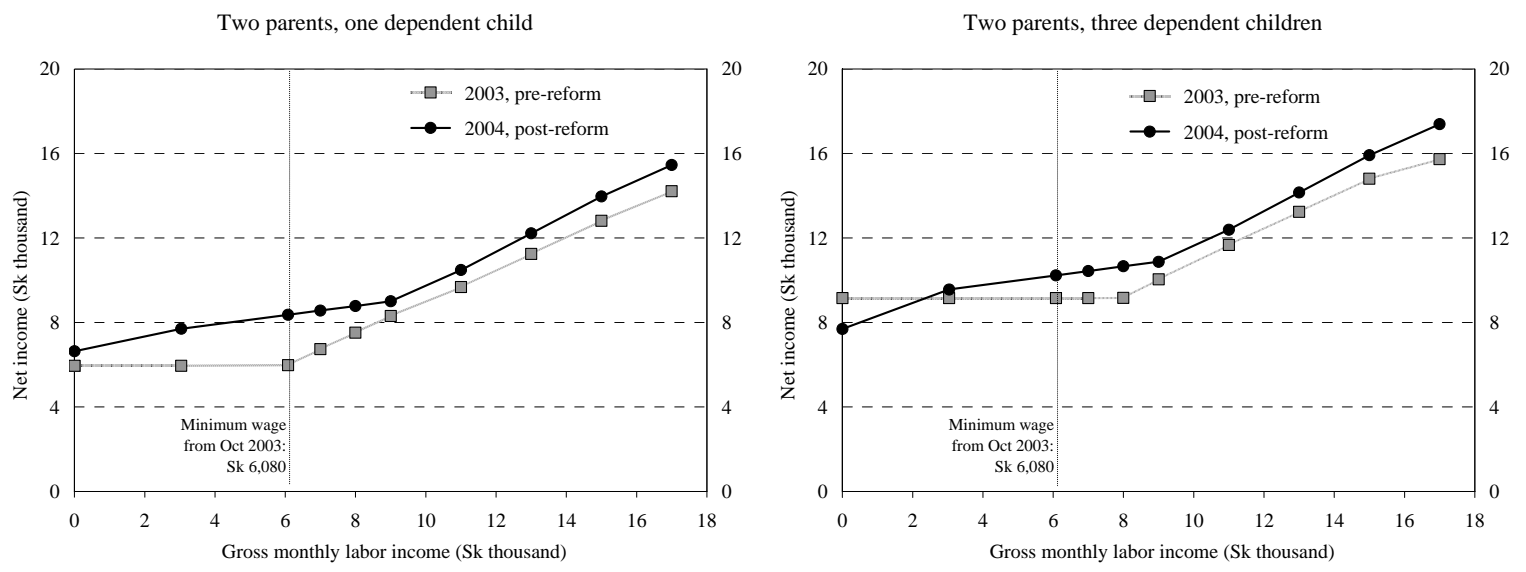

Single parent, three dependent children

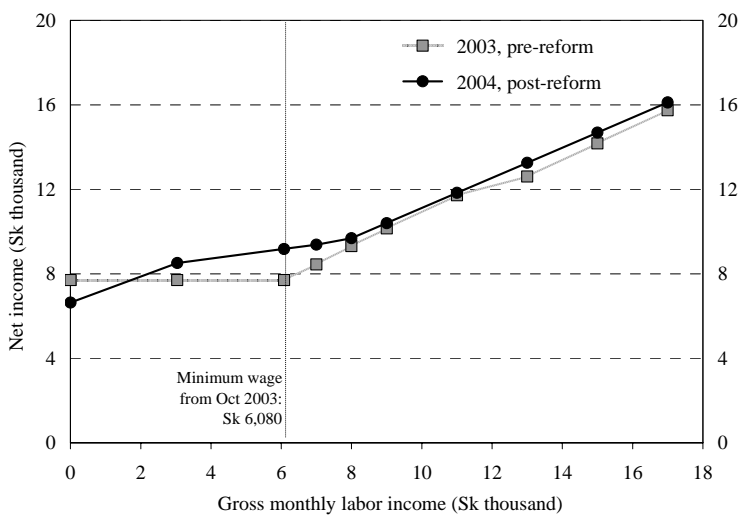

Two parents, five dependent children

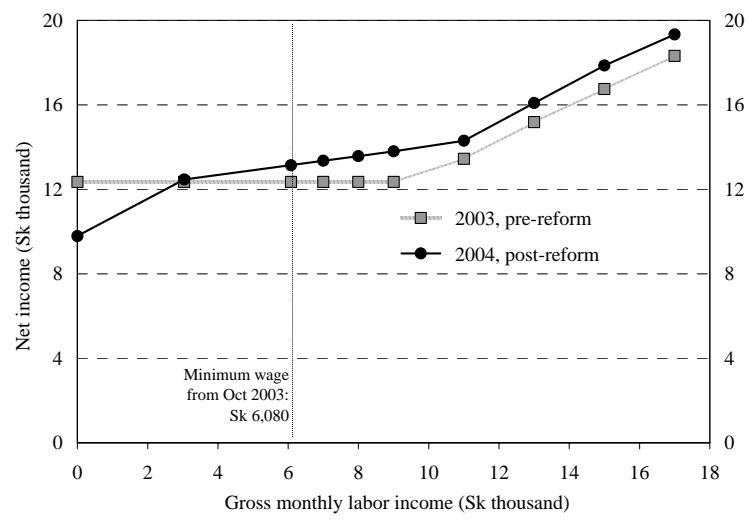

Source: From calculations in Slovak Ministry of Labor, Social Affairs and Family (2004) 


\section{FISCAL EFFECTS OF THE REFORMS: FIRST RESULTS}

\section{Tax Reform}

Data for 2004 point to a modest overall impact on revenue following the tax reform. Cash-basis data show significantly better than budgeted collections of most taxes, notably income taxes (Table 1), albeit implying a small reduction in taxes as a share of GDP. However, because of delays in collections of indirect taxes following EU accession, the accrual-basis data present a more mixed picture.

Tax revenues fell as a share of GDP in 2004. With economic growth better than budgeted, tax revenues in 2004 declined by 0.7 percent of GDP from 2003. The decline is greater after taking into account 1 percent of GDP in one-off VAT refunds paid in 2003 following a change in the VAT law in 2002 (Figure 4).

Figure 4. Slovak Republic: Tax Structure

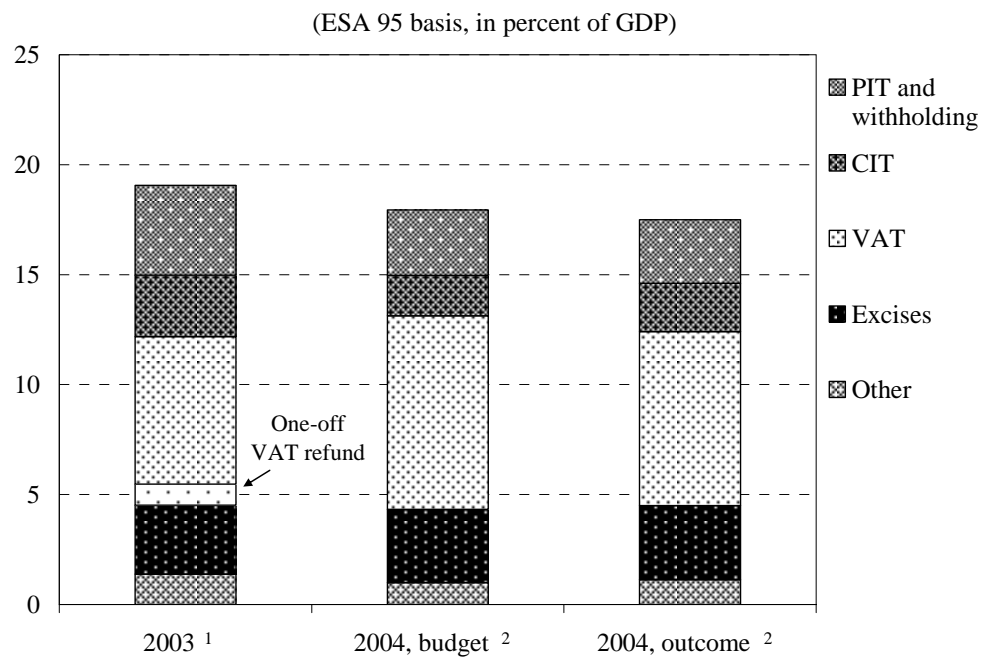

Sources: Slovak Ministry of Finance and IMF staff estimates.

${ }^{1}$ The 2003 total is adjusted to include about 1 percent of GDP in one-off VAT refunds paid in

2003 following a change in the VAT law in 2002

${ }^{2}$ The 2004 calculations are based on different projections of nominal GDP:

Sk 1,293 billion (budget) versus Sk 1,325 billion (outcome). 
Income tax losses due to the reform seem broadly in line with expectations, after accounting for cyclical developments. As a share of GDP, income taxes have evolved largely as expected by the Ministry of Finance and by the IMF at the time of the 2003 Article IV Consultation (Table 2):

- PIT collections (wage tax and self-employment tax) were significantly better than projected, reflecting higher-than-projected growth in economy-wide wages in 2004.

- CIT collections were also slightly stronger than projected.

- On the other hand, collections of withholding taxes on capital income (including the tax on dividends) were significantly less than projected. Some of these taxes have been diverted to CIT collections: firms may now be reporting, as profits, income that was previously taxed at a lower rate as capital income. Moreover, companies apparently retained earnings in 2004, rather than paying out dividends, to avoid the final year of dividend tax.

\begin{tabular}{|c|c|c|c|}
\hline \multicolumn{4}{|c|}{$\begin{array}{l}\text { Table 2. Estimated Impact of the } 2004 \text { Tax Reform } \\
\text { (ESA } 95 \text { basis, in percent of GDP) }\end{array}$} \\
\hline & $\begin{array}{c}\text { MoF } \\
\text { Projected } \\
\text { impact }\end{array}$ & $\begin{array}{c}\text { IMF } \\
\text { Projected } \\
\text { impact }\end{array}$ & $\begin{array}{c}\text { Change from } \\
2003 \text { outcome } \\
\text { Actual }\end{array}$ \\
\hline Taxes on income & -1.5 & -1.8 & -1.8 \\
\hline Taxes on employment income & -0.9 & -1.2 & -0.8 \\
\hline Self-employment tax & -0.2 & -0.2 & 0.0 \\
\hline Corporate income tax & -0.6 & -0.5 & -0.6 \\
\hline Withholding income tax ${ }^{1}$ & 0.2 & 0.2 & -0.3 \\
\hline Taxes on goods and services & 1.9 & 1.8 & 1.4 \\
\hline Value-added tax & 1.4 & 1.3 & $1.2^{2}$ \\
\hline Excise duties & 0.5 & 0.5 & $0.2^{3}$ \\
\hline Other taxes & -0.1 & -0.1 & -0.2 \\
\hline Taxes on property & 0.0 & 0.0 & 0.0 \\
\hline Road tax & 0.0 & 0.0 & 0.0 \\
\hline Customs duties & 0.0 & 0.0 & $-0.2^{4}$ \\
\hline Total & 0.3 & 0.0 & -0.6 \\
\hline \multicolumn{4}{|c|}{$\begin{array}{l}\text { Sources: IMF Staff Report for the } 2003 \text { Article IV Consultation; and Ministry of Finance. } \\
{ }^{1} \text { Projections assumed revenue impact in } 2005 \text { from abolition of dividend taxation. } \\
2 \text { This estimate is subject to offsetting distortions. } 2003 \text { collections were lower } \\
\text { by } 1 \text { percentage point of GDP, owing to one-off refunds paid following a change } \\
\text { in the VAT law in } 2002.2004 \text { collections may be lower owing to EU accession. } \\
{ }^{3} \text { The increase in excises was brought forward to August } 2003 \text {. Also subject to } \\
\text { lower collections in } 2004 \text { following EU accession. } \\
{ }^{4} \text { Following EU accession, customs duties became EU rather than national revenue. }\end{array}$} \\
\hline
\end{tabular}

Indirect tax collections increased by less than previously projected, reflecting several additional factors that are difficult to disentangle from the tax reform. As Section II noted, the reform intended to offset lower income tax collections with higher indirect tax 
collections, thus achieving broad revenue neutrality. Indirect tax collections were indeed higher in 2004 (Table 2), despite the increase in excise tax rates having been brought forward to August 2003. But collections of indirect taxes have been affected by factors other than the tax reform, especially tax administration changes required upon EU accession. The shift in tax collection responsibilities from customs offices to tax offices ${ }^{6}$ resulted in delays in collections from mid-2004 and losses in efficiency. It remains to be seen whether these efficiency losses are temporary or longer-lasting. Also, the lowering of the VAT registration threshold required administering many extra small taxpayers.

\section{Social Contributions}

Social contributions fell by more than expected following the reduction in rates. The 2004 budget implied a 0.8 percent of GDP reduction in social contributions from $2003 .{ }^{7}$ However, collections fell short of budget by a further 0.2 percent of GDP, with the shortfall mainly in collections by the Social Insurance Agency. Revenue losses from lower social contributions are of similar magnitude to the losses from the reform of state budget taxes (Figure 5).

Figure 5. Slovak Republic: Tax Structure, including Social Contributions

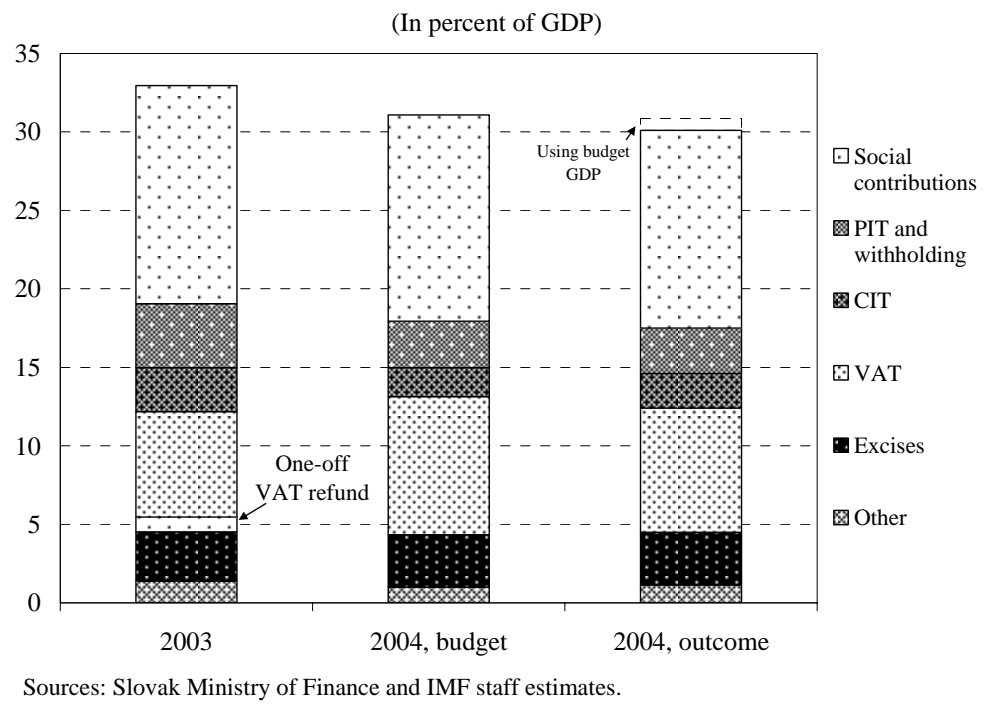

6 Applicable for EU-source imports. Because of this shift, the accrual-basis estimates for VAT and excises are much more uncertain than those for income taxes.

7 Based on budgeted GDP. If based on actual GDP, the reduction would be 1 percentage point of GDP. 


\section{Welfare Reforms}

The welfare reforms have improved control of welfare spending. In 2001 and 2002, spending on state benefits and social assistance ran over budget by about 0.3-0.4 percent of GDP annually (Figure 6), reflecting benefit abuse as well as underbudgeting. The 2003 measures were successful in curbing benefit abuse, bringing welfare spending down by 0.3 percentage points of GDP, and even achieving savings of 0.1 percent of GDP compared to budget. Following the 2004 reform, welfare spending fell by another 0.6 percentage points of GDP, and was 0.4 percent of GDP below the 2004 budget ceiling, mainly on account of lower than budgeted spending on child allowances.

Figure 6. Slovak Republic: State Benefits and Social Assistance

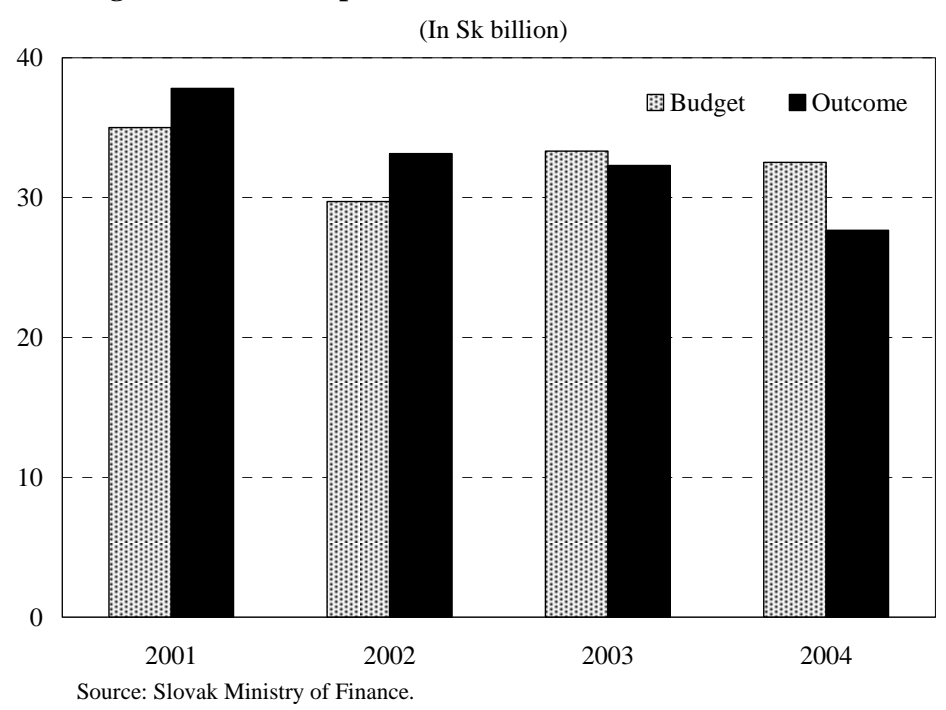

\section{EFFICIENCY AND INCENTIVES}

In efficiency terms, the reforms provide several gains. The tax reforms reduce distortions in the economy, and the simpler tax system should allow for significant improvements in tax administration. Regarding incentives to work, the tax reform may result in only marginal improvements in incentives to work and to hire-labor taxes have fallen only modestly for many taxpayers; and the tax burden has been shifted towards labor, away from capitalthough the welfare reform should significantly improve work incentives for lower-income earners.

\section{Benefits from Tax Simplification}

The reform reduces distortions in the tax base. Though the impact is hard to measure, the reduction in tax exemptions is an obvious gain to the economy. First, resource allocation is generally more efficient if based on market rather than tax signals. Second, it implies higher revenue for a given tax rate, which allows taxes to be set at lower rates. Third, it promotes transparency; many of the tax exemptions were in fact tax expenditures, implying a diversion 
of public resources to these sectors without the budgetary scrutiny that would accompany other expenditures.

The reformed tax system is much simpler and easier to administer. The system is simpler for taxpayers, who no longer face different tax rates for different types of income or commodity. Moreover, the Slovak Ministry of Finance (2003b) notes that business surveys had identified the complexity and frequent changes in the tax law as one of the main barriers to business. The reform is also promising for tax administration and compliance. Taxpayers no longer need to report different types of income, nor to account separately for standard-rate and reduced-rate commodities; the tax authorities no longer have to enforce the distinctions; and resulting litigation (on both sides) should fall.

The single-rate VAT should be particularly helpful in addressing long-standing problems with refunds. Given the wide range of commodities subject to the lower rate, it had been possible in some sectors, for example construction, to claim refunds on inputs at the higher VAT rate and sell output taxed at the lower rate. Outright fraud also contributed to refund problems. Indeed, in 2002, VAT refunds had exceeded domestic VAT collections. ${ }^{8}$

The single rate for personal and corporate income tax reduces, though does not eliminate, opportunities for tax arbitrage. The multiple rates of withholding tax, as well as different rates for wage-income and profit tax, had offered considerable scope for tax arbitrage. For example, under the previous system, owners of large businesses could deduct interest expenses at a rate of more than 30 percent, while maintaining interest assets in the household that were subject to withholding tax of only 5 or 15 percent. This is no longer possible. However, with employment (including self-employment) income subject to payroll taxes, there are incentives for self-employed persons to convert employment income into capital income.

\section{Incentives to Work}

\section{Tax Reform and the Composite Tax Rate}

High marginal tax rates are widely recognized as dampening incentives to work. Disney (2000) notes that research has focused on the impact of marginal tax rates on labor supply at the upper and lower ends of the income distribution. For upper-income earners, the issue is also participation in the tax system: this group may be more likely to receive non-monetary forms of remuneration and have greater access to sophisticated tax avoidance schemes. The "Laffer curve" theory suggests that cutting tax rates on these taxpayers can actually increase

\footnotetext{
${ }^{8}$ Comparable data are not available for 2003, owing to the one-off VAT refunds paid that year.
} 
total tax revenue. ${ }^{9}$ For lower-income earners, the relevant decision may be not only how much labor to supply in terms of hours worked, but whether to participate in the labor market at all. For this group, the welfare system also critically affects labor supply decisions (see below).

Evidence is mixed on whether the structure of labor taxes significantly affects unemployment. Nickell (1997) argues that the relevant tax rate for the labor market is the sum of the payroll, personal income, and consumption tax rates; and that payroll taxes will be shifted onto workers assuming capital is mobile internationally. Consumption taxes including the VAT may be regarded as labor taxes in the long run, because neither a tax on consumption nor a tax on labor income directly affects the return that can be achieved on savings. Nickell cites several studies that find no long-run effect on unemployment from lowering payroll taxes and increasing consumption taxes - though the overall tax burden might matter. However, Daveri and Tabellini (2000) argue that payroll taxes drive a wedge between employment income and benefit or underground-economy income; in contrast, consumption taxes affect these income sources equally. Using data for continental Europe, Daveri and Tabellini find that a 14 percent increase in labor tax rates can be associated with a 4 percentage point increase in the unemployment rate; but they find no statistically significant link between consumption taxes and unemployment. Nickell (2004) has countered that the Daveri-Tabellini results are biased upward because they do not control for other labor market institutions.

The analysis below considers labor taxes as a composite of income, payroll, and consumption taxes. The measure used here includes both employee and employer payroll taxes, thus taking into account the "tax wedge", that is, the gap between the cost of labor to an employer and the net benefit to an employee. From the employer's labor demand perspective, gross wages and payroll tax costs are equivalent. From the worker's labor supply perspective, the relevant variable is income net of all taxes, including consumption taxes, which-like income taxes-reduce the benefit to the employee from additional hours worked. Thus, the composite marginal tax rate of labor taxation is measured here as:

$$
\mathrm{C}=100 \times[1-(1-\mathrm{t})(1-\mathrm{c}) /(1+\mathrm{v})(1+\mathrm{p})]
$$

where, $\mathrm{t}$ is the marginal income tax rate on wages;

$\mathrm{c}$ is the rate of employee social insurance contribution, in percent of gross wages;

${ }^{9}$ Disney (2000) reports that studies on this effect suggest that taxable income tends to respond positively to tax cuts, but not so strongly as to generate Laffer effects. Moffitt and Wilhelm (1998) find, using data for the United States, no responsiveness of the hours of work of high-income men to the 1996 tax reduction, which reduced marginal tax rates for the affluent more than for other taxpayers. 
$\mathrm{v}$ is the marginal (tax-exclusive) rate of indirect taxation on net wages; ${ }^{10}$

$\mathrm{p}$ is the rate of employer social insurance contribution, in percent of gross wages.

The Slovak reform changes the tax structure, but reduces labor taxes only modestly for many taxpayers. At very low levels of income, the marginal tax rate is above zero because of indirect taxes; the initial increases reflect the minimum thresholds for social contributions. The highest marginal tax rates are at middle-income levels:

- Under the previous system, the composite marginal tax rate increased with income, up to Sk 32,000 monthly, before leveling off. Further increases in the income tax scale were offset by the fall in social contributions to zero, because social contributions are not payable on income above the maximum assessment base, then Sk 32,000 .

- Following the reform, the composite tax rate falls sharply after income reaches the maximum assessment bases for social contributions.

Composite marginal tax rates have moved in different directions for single and married taxpayers. Figures 7 and 8 show the change in the composite marginal tax rate for two cases: a single taxpayer, and a taxpayer with a non-working spouse and two dependent children. In both cases, the largest cuts in the composite marginal tax rate appear above monthly incomes of Sk 32,000 — a little over twice the average wage (Sk 14,365 in 2003).

- For single taxpayers, composite marginal tax rates increased on gross monthly incomes between Sk 8,000 and Sk 13,000 in 2004: modest income tax relief at low income tax levels was more than offset by increases in both employee social contributions and indirect taxes.

- In contrast, for married taxpayers with a non-working spouse and dependents, the reform implies cuts in composite marginal tax rates (except for high income ranges affected by the increase in the maximum assessment bases for social contributions) because of the large tax-free threshold from including the non-working spouse.

Note that for a married taxpayer, the tax reduction would imply stronger incentives to work for one of the couple. However, the exemption for the non-working spouse is as generous as for a working spouse; thus the spouse faces a high marginal tax rate upon entering the workforce, since income tax would be payable on the first koruna of the spouse's earnings.

\footnotetext{
${ }^{10}$ Because the indirect tax burden appears not to vary widely across household income (see Section V), the calculations below use the average rate of indirect taxation for simplicity.
} 
Figure 7. Composite Marginal Tax Rate, Single Taxpayer

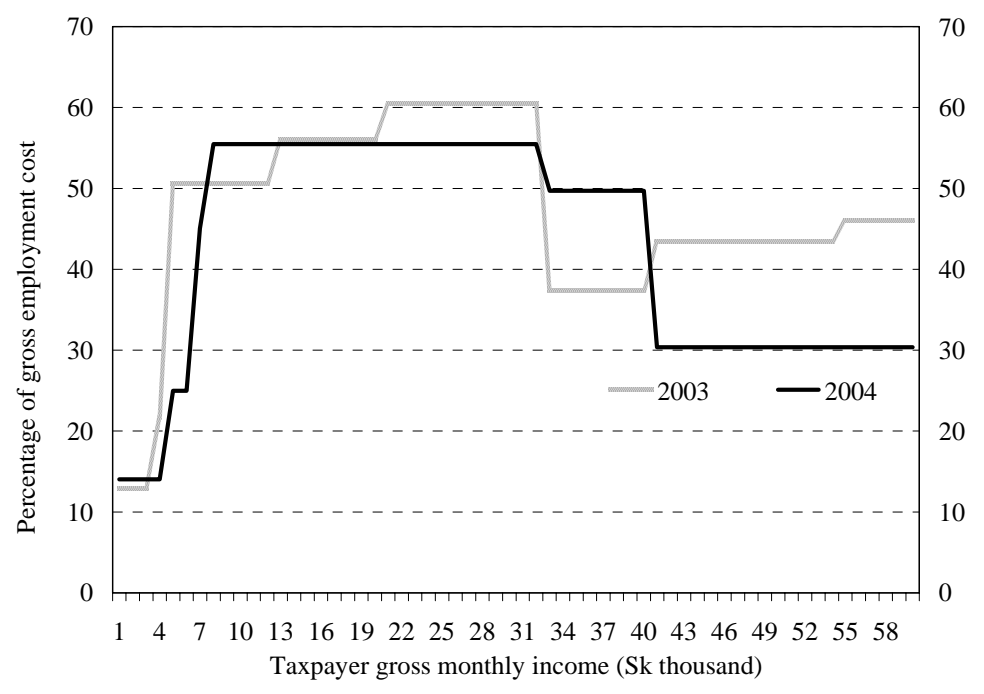

Figure 8. Composite Marginal Tax Rate, Married Taxpayer (with non-working spouse and two children)

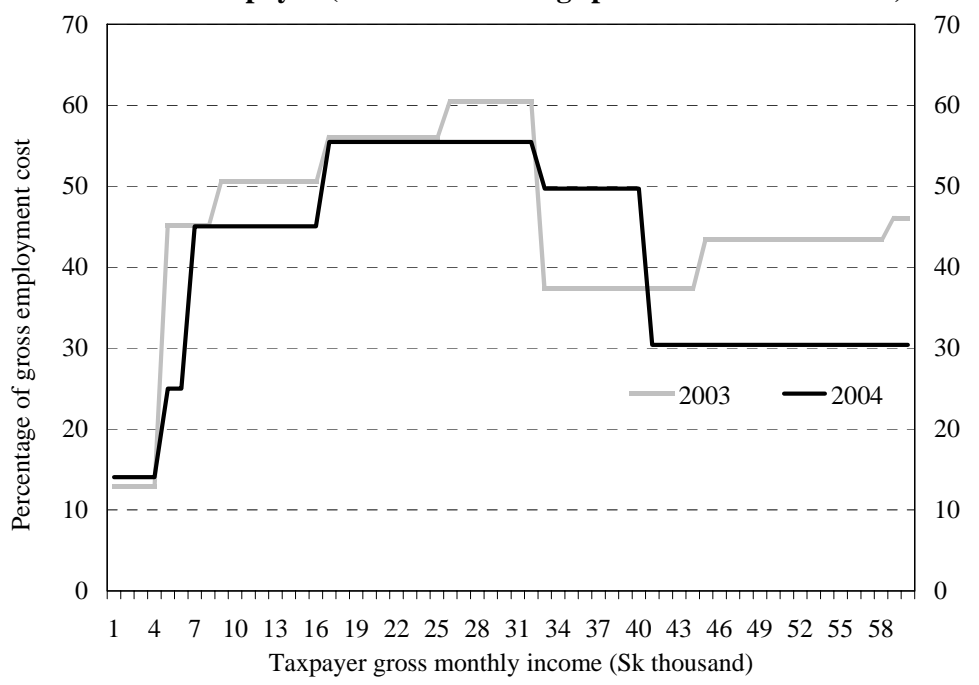

Social contribution rates — and thus, the tax wedge—-remain high by regional standards. Table 3 shows that overall payroll tax rates remain the highest of the Visegrad ${ }^{11}$ countries, and well above the average in western Europe. Consequently, these payroll taxes contribute to a still-high tax wedge, whether or not consumption taxes are included in the wedge.

Figure 9 shows the tax wedge pre- and post-reform, for four different points on the wage

11 Czech Republic, Hungary, Poland, and Slovakia. 
distribution for a single taxpayer, using the OECD "Taxing Wages" measure ${ }^{12}$ which excludes consumption taxes. At each point, Slovakia's tax wedge remains above the OECD average. The World Bank (2001) suggests that high payroll taxes may have a bias against unskilled labor, because for higher-skill workers it is easier to provide both wage and nonwage compensation. Moreover, the Daveri-Tabellini (2000) results suggest that capital-labor substitution - and the attendant increase in unemployment — can be significant in the presence of high tax wedges.

\begin{tabular}{|c|c|c|c|}
\hline \multicolumn{4}{|c|}{$\begin{array}{c}\text { Table 3. Social Contribution Rates } \\
\text { Selected European Countries, percent of Gross Labor Income }\end{array}$} \\
\hline & Employee & Employer & Total \\
\hline \multirow[t]{2}{*}{ Slovak Republic } & 12.8 & 38.2 & 51.0 \\
\hline & 13.4 & 35.2 & 48.6 \\
\hline Czech Republic & 12.5 & 35.0 & 47.5 \\
\hline Hungary & 12.5 & 32.0 & 44.5 \\
\hline Poland & 25.0 & 20.4 & 45.4 \\
\hline EU-15 average ${ }^{2}$ & 12.5 & 24.1 & 36.6 \\
\hline \multicolumn{4}{|c|}{ Sources: Ministry of Finance (2004); and OECD statistics. } \\
\hline \multicolumn{4}{|c|}{$\begin{array}{l}{ }^{1} \text { Unless otherwise indicated, data refer to } 2003 \text { and are based on the average } \\
\text { production wage. } \\
{ }^{2} \text { Unweighted; excludes Denmark. }\end{array}$} \\
\hline
\end{tabular}

Figure 9. Tax Wedges and Earnings (OECD measure, single taxpayer)

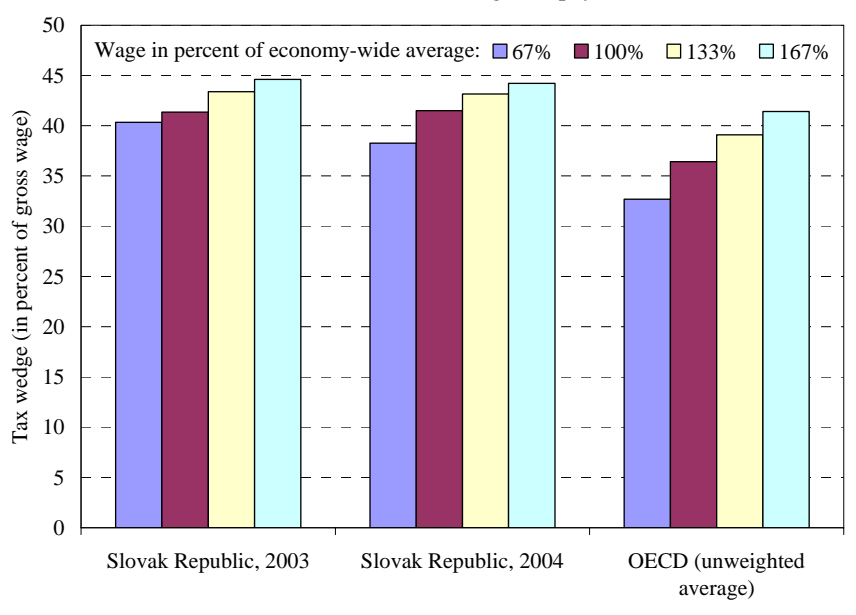

Source: OECD and IMF staff calculations.

12 The sum of central and subnational income taxes and employee and employer social contributions, measured in percent of gross wage plus employer social contributions. 


\section{Welfare Reform and the Marginal Effective Tax Rate}

Low-income earners face marginal effective tax rates arising not only from the tax system, but also from the benefit system. The composite tax rate above has implications for the labor supply response of middle- and high-income earners; but for lower-income earners, work incentives may be just as strongly influenced by the benefits system. The marginal effective tax rate (METR) is the rate at which an individual loses net income-whether through higher income taxes or withdrawal of benefits - as gross non-welfare income increases. ${ }^{13}$

More formally, following Disney (2000):

$$
\operatorname{METR}=1-\left[w\left(1-t_{w}-c\right)-b\left(1-t_{b}\right)\right] / w\left(1-t_{w}-c\right)
$$

where, $b$ is the level of benefit, $w$ is the gross wage, $t$ is the income tax rate, and $c$ is the employee payroll tax rate.

High METRs create strong disincentives to work, resulting in two types of "trap". ${ }^{14}$ The unemployment trap arises when benefits are so high relative to the potential wage that an individual chooses not to participate in the labor force. The poverty trap arises when an individual is unable to increase their disposable income by increasing their work effort. The Slovak benefit reforms aimed to address these traps.

Interactions between the Slovak tax and welfare systems are mainly through payroll taxes and income tax credits. The linkage via income tax is limited. Before the 2004 reforms, social assistance benefits-like other social income such as pensions-were exempt from income taxation. Following the reforms, social income is legally taxable, but in practice the tax liability is zero in most cases because of the high tax-free thresholds for both individuals and families. However, part of child support is now delivered through the income tax system (up to Sk 4,800 annually per child when at least one parent is employed). Although income tax thresholds are relatively high, social contributions are payable from very low levels of income. This means that they contribute to the marginal effective tax rate, though for welfare recipients, they do not add to the rate; withdrawal of benefits as labor income increases is on the basis of income after tax.

Even with limited tax-benefit interactions, Slovakia's welfare system generated prohibitively high METRs. The former "top-up" system of income assistance-with benefits withdrawn one-for-one when a recipient earned non-welfare income-implied an METR of 100 percent (actual METRs were even higher taking into account transportation and other costs).

\footnotetext{
${ }^{13}$ See, for example, OECD (1997) and Disney (2000)

${ }^{14}$ OECD (1997), Carone and Salomäki (2001).
} 
The welfare reforms have reduced METRs for most welfare recipients. The authorities had aimed to reduce METRs of around 100 percent to around 75 percent, by allowing welfare recipients to keep 25 percent of non-welfare income (Slovak Ministry of Labor, 2004). Indeed, the household examples from Section II confirm that METRs of 100 percent for welfare recipients with no other income or earning minimum wage have indeed been reduced. Figure 10 shows the corresponding METRs that these households face before and after the reform.

The METR reduction helps address especially strong work disincentives for parents with large families. As noted in OECD (1997), METRs cause greatest disincentives not only when they are high, but when they apply over extensive income ranges. The bottom right panel of Figure 10 shows that for a family with five children, the METR had been 100 percent even at monthly incomes approaching double the minimum wage, a wider income range than for smaller families.

Figure 10. Marginal Effective Tax Rates

Two parents, one dependent child

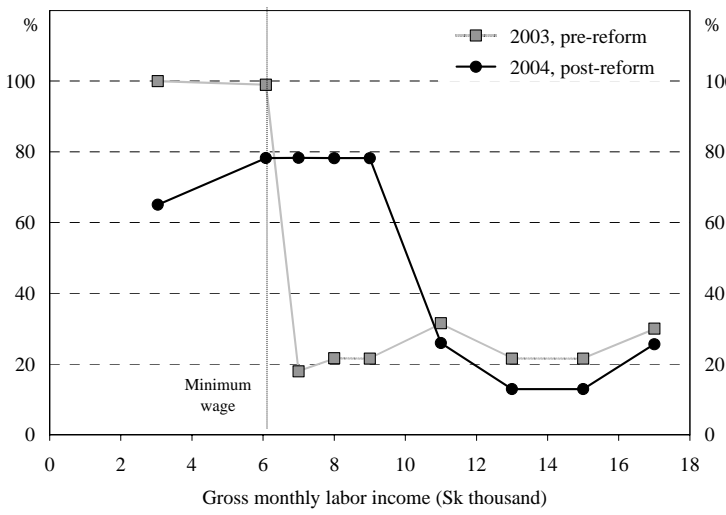

Single parent, three dependent children

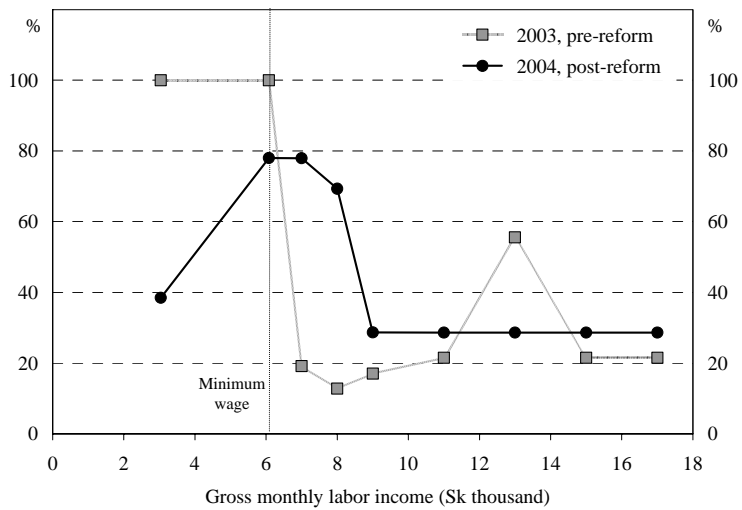

Source: calculations based on labor income and net income scenarios from Figure 3.
Two parents, three dependent children

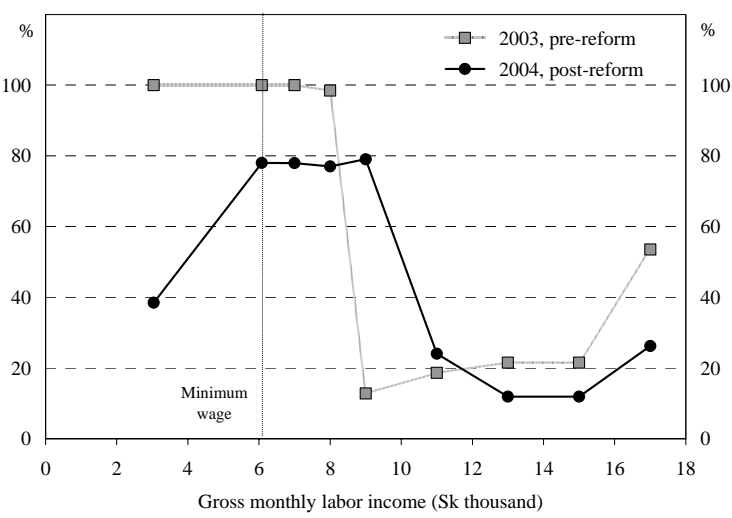

Two parents, five dependent children

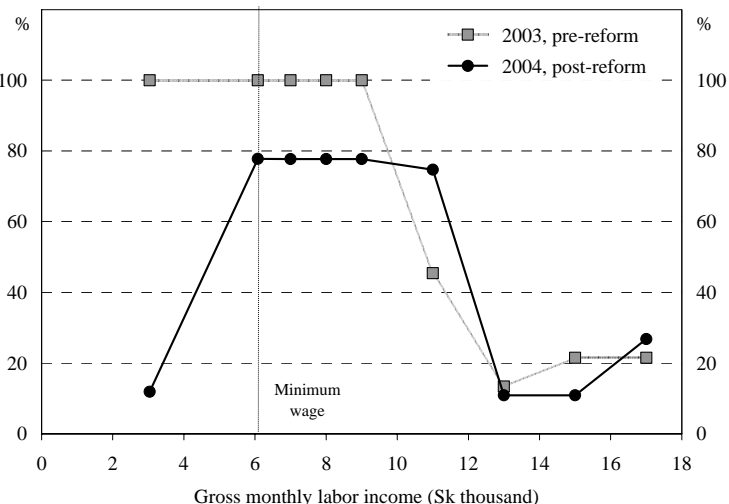




\section{Welfare Reform and Other Effects on Work Incentives}

The introduction of the activation program is also a critical measure to improve work incentives. The activation allowance now accounts for a significant share of the benefit, approaching 50 percent in some instances, creating an obvious incentive for the effort to qualify. Experience with activation policies in other countries have generally been successful. The OECD (2003) reports that activation strategies have boosted employment and reduced benefit dependency in several countries, even those (such as Sweden) with relatively generous benefits. However, the OECD stresses the importance of labor demand in this success, warning that it may be difficult to achieve a large employment impact where there are very few job openings.

The restructured child allowances also should improve work incentives, though at the cost of some efficiency in targeting. In contrast to the former system, means-testing is not applied either to the Sk 500 monthly flat, universal allowance, or to the Sk 400 monthly tax bonuswhich is conditional on at least one parent being employed. Carone and Salomäki (2001) note that a frequent side-effect of in-work benefits is that they are phased out as income rises, potentially increasing marginal effective tax rates; this is not a problem in the new Slovak system, which does not phase out the restructured child allowances.

\section{Recent Employment Developments}

The employment response has been modest so far. Economy-wide employment growth stagnated in the first three quarters of 2004, despite strong economic growth (Figure 11). Ministry of Labor officials note that weak employment growth partly reflects significant public sector layoffs during 2004, including in public enterprises. Fourth quarter data suggests employment has started to recover, ${ }^{15}$ but the recovery remains subject to two key risks. First, the shift in the tax burden could contribute to entrenching the recent bias of economic growth towards capital-intensive activity. Second, and relatedly, the reforms should contribute strongly to labor supply, but labor demand remains weak, especially in many of the high-unemployment areas. ${ }^{16}$

15 See Choueiri (2005).

16 The IMF (2005) discusses the structural measures envisaged by the authorities to help reduce unemployment. 
Figure 11. Economic Growth and Employment, 1999-2004

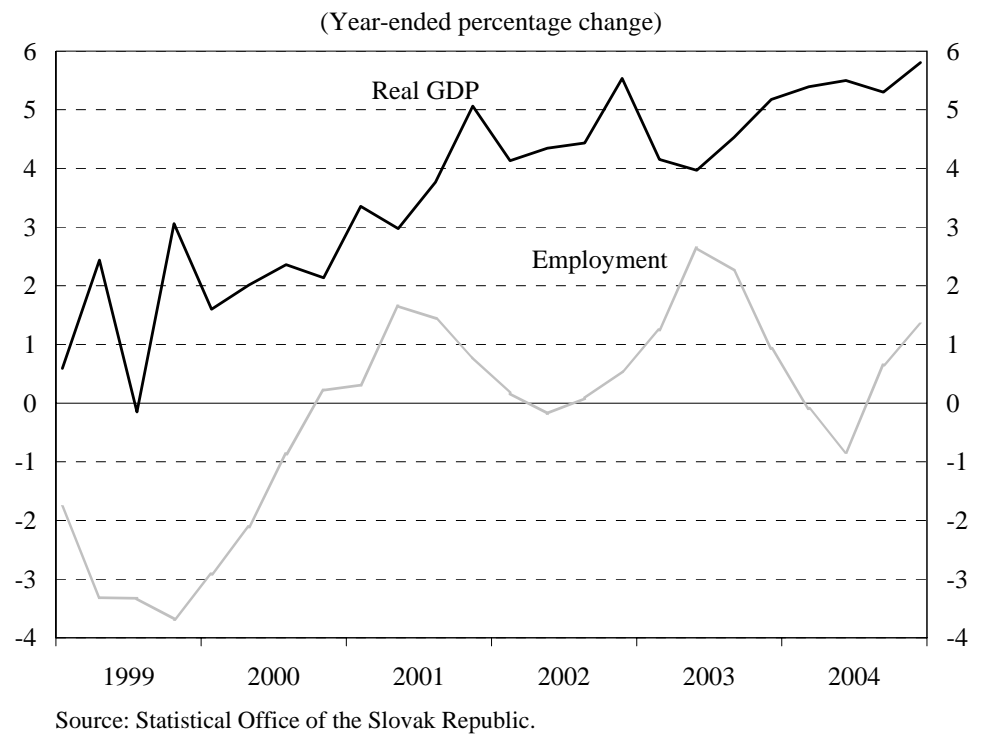

\section{Tax Reform and Investment}

The tax burden on capital has been reduced significantly. The new CIT rate of 19 percent compares to a rate of 40 percent in 1999. Moreover, the abolition of dividend taxation implies that investment income is now taxed only once.

The CIT rate is now low by EU standards, prompting claims of tax competition. Figure 12 shows that the CIT rate, which had been above the EU average, is now slightly below both the EU average and the average of the new member states. One sign that the Slovak reforms are indeed attractive to foreign investors is the reaction of neighboring countries: Goliaš (2004) notes that Austria, which had intended to reduce its CIT rate from 34 to 31 percent, instead announced a reduction to 25 percent from 2005; and that Hungary reduced its CIT rate from 19.6 to 17.7 percent.

But CIT collections remain comparable to EU averages. Slovak CIT revenue as a share of GDP was 2.3 percent of GDP in 2004, close to the latest observations ${ }^{17}$ for CIT revenues in both the EU-15 and EU-25 (2.4 percent each).

Besides the low CIT rate, the liberalized treatment of loss carryforwards assists businesses. Losses can now be deducted from taxable income over the following 5 years, and annual write-off installments are no longer required to be equal. The previous treatment of losses had detracted significantly from the competitiveness of the CIT law. Private accountants in Slovakia informed a 2003 IMF Fiscal Affairs Department mission that their clients were more concerned about their inability to write off legitimate losses, than whether the CIT rate

17 For 2002; see European Commission (2004). 
was 15 or 25 percent. Including the inability to write off advertising expenses, some clients faced effective tax rates of 35 percent or more (in some cases reaching 80 percent), despite the then statutory CIT rate of 25 percent. The new CIT law remedies this problem.

Figure 12. Corporate Income Tax Rates, 1995-2004

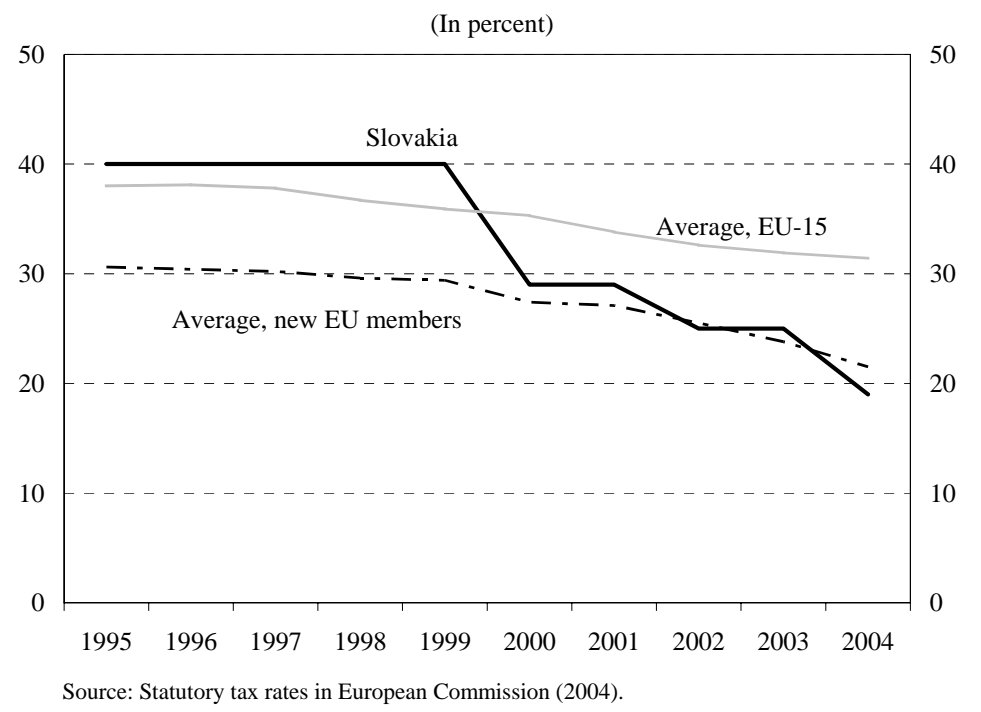

\section{DISTRIBUTIONAL IMPLICATIONS}

This section explores some of the distributional implications of the reforms. Two questions are particularly relevant: first, what are the distributional effects of the reformed tax system: is the tax system progressive, neutral or regressive? Second, is the social safety net still effective, and does the reformed welfare system adequately protect the most vulnerable members of society?

\section{The Tax System}

Excluding social contributions, the tax system remains progressive overall, though less so than previously. However, the distributional implications of the tax system vary depending on the degree to which social contributions are regarded as taxes.

\section{Income Taxes}

Assessing the progressivity of an income tax is relatively straightforward. In general, an income tax is progressive if the average tax rate increases as income increases (see for example, Norregaard, 1995).

The reformed personal income tax remains progressive, though the reform reduces the degree of progressivity. Figure 13 shows that, following the tax reform, the average income tax rate rises with income over the whole income distribution, though less steeply than before the reform. This is because the tax-free threshold, or the personal exemption, is significant. The 
average effective tax rate rises much more slowly for a married taxpayer with a non-working spouse - because this taxpayer qualifies for a double exemption-and the taxpayer also receives a further tax deduction for each child.

Other things equal, the simplification of income tax would contribute to horizontal equity. The cancellation of different tax rates for different income types, and of most income tax exemptions, greatly reduces the number of taxpayers who have an equal ability to pay nevertheless being subject to different tax burdens.

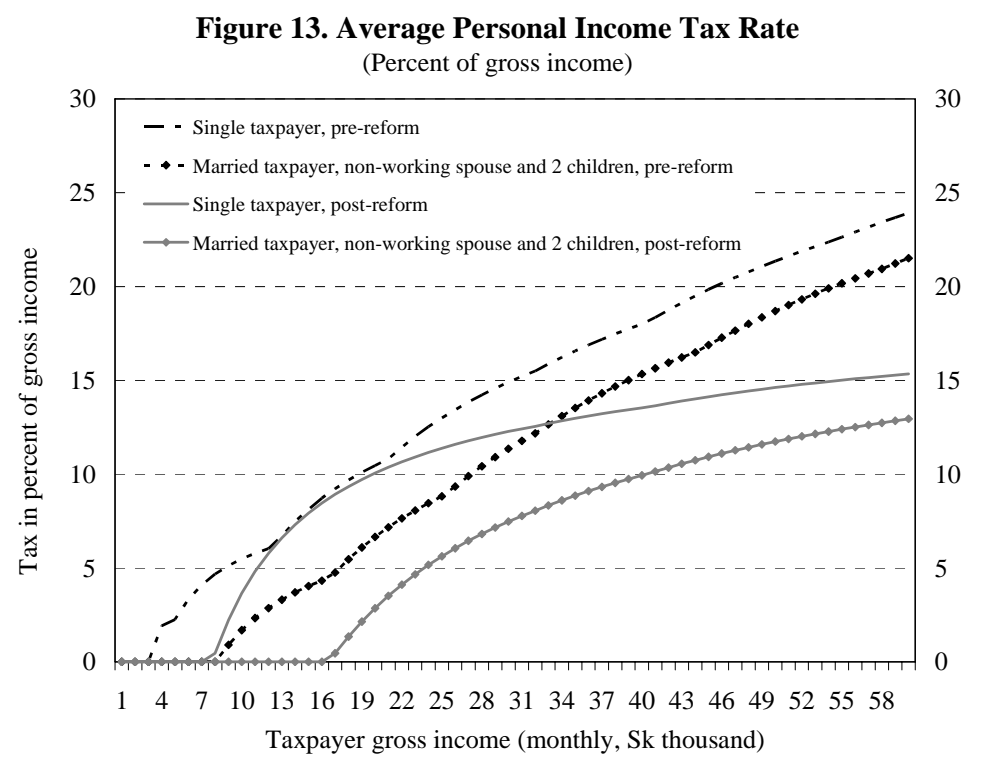

\section{Indirect Taxes}

Under the previous two-rate VAT in Slovakia, the lower VAT rate provided relatively little benefit to poorer households. Figure 14 shows the estimated VAT burden as a percentage of net household income, using data from the Statistical Office's Microcensus survey. Prereform, the burden was very similar across decile groups of household net income, in part reflecting the wide range of non-necessity goods and services (including construction, for example) that were taxed at the lower rate. Even at the single rate, the estimated burden is around 14-15 percent for most income groups, though slightly lower for the highest income decile.

Excise taxes appear to have limited distributional effects. Figure 15 suggests that the excise tax burden is broadly proportional across household income. The tax on motor fuels is mildly progressively distributed, offsetting tobacco excises, which appear mildly regressively distributed. 
Figure 14. VAT Burden and the Income Distribution

(In percent of household income, by decile groups of household net income)

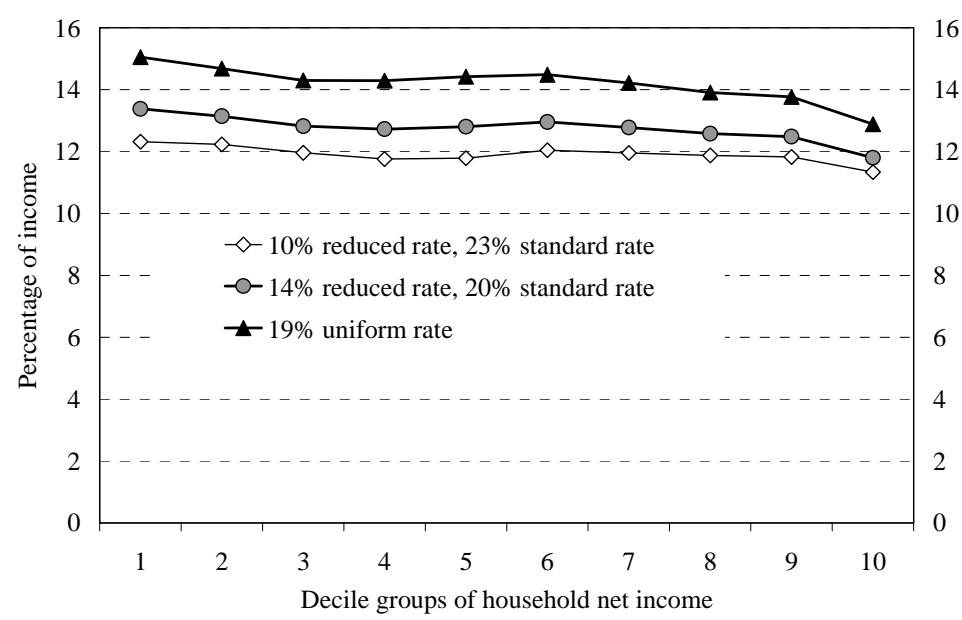

Source: Based on household net income data from Microcensus.

Figure 15. Excise Tax Burden and the Income Distribution

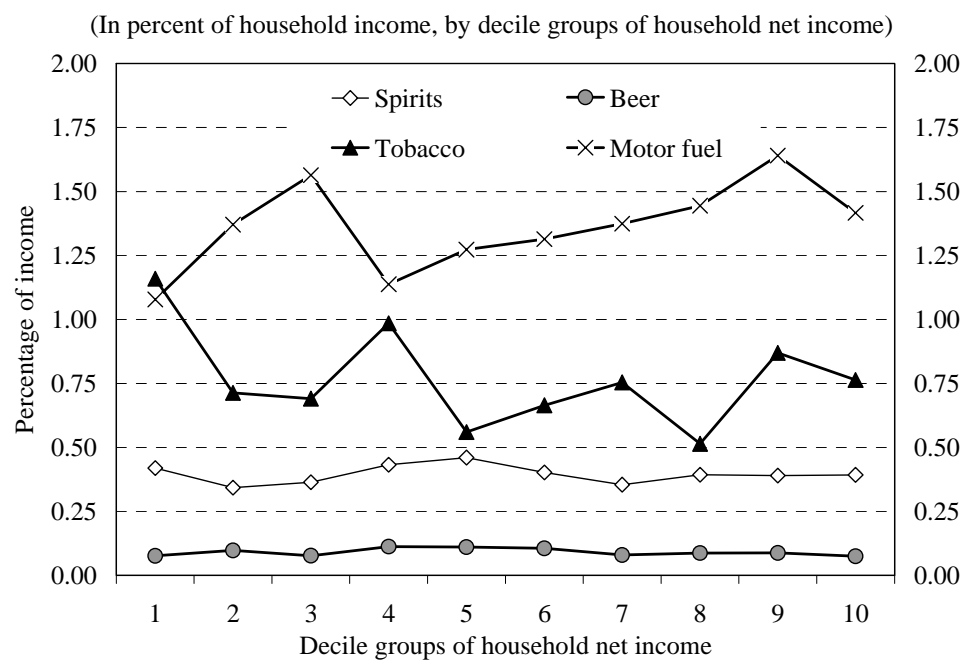

Source: Based on household net income data from Microcensus.

\section{Social Contributions and the Average Composite Tax Rate}

Treating social contributions as part of the tax system introduces a regressive component. Social contributions closely resemble taxes, in that both are mandatory charges on income paid to general government agencies. ${ }^{18}$ Social contributions are payable up to a "maximum assessment base" for each type of contribution, implying that the marginal social contribution

${ }^{18}$ Except for pension contributions to the second pillar effective from 2005, which will be outside general government. 
rate falls to zero for income above these maximums. Thus, for high-income earners, the average effective social contribution rate payable must fall as income rises.

At one extreme, including social contributions would imply that the overall tax system becomes regressive for the highest-income earners. Figure 16 shows the average composite tax rate, based on the Section IV measure including employee but not employer contributions. Prior to the reform, the average composite tax rate rose with income, reflecting the flattening in the marginal rate for incomes above Sk 32,000 per month. Following the reform, the decline in the composite marginal rate for incomes above Sk 40,000 per month, or nearly 3 times the average wage, implies that the overall tax burden turns regressive in the high-income range.

A small proportion of taxpayers are in this high-income range beyond the social contribution ceiling - perhaps around 1 percent - though this estimate should be treated cautiously. Data from 2003 tax returns show that some 25,000 taxpayers filed income tax returns for the tax bracket above Sk 396,000 (Sk 33,000 monthly), of whom some 14,000 filed returns for the bracket above Sk 564,000 (Sk 47,000 monthly: above all social contribution ceilings even after the 2004 increases). However, these data do not include the many wage earners whose tax liabilities are satisfied by withholding and therefore do not file tax returns. To get a sense of the proportion of taxpayers in this range, the nearest comparator is total employment from the labor force survey (2.2 million in 2003). On this basis, 0.6 percent of taxpayers have monthly incomes above Sk 47,000, well above the ceilings for all types of social contributions.

Figure 16. Average Composite Tax Rate (Percent of gross employee income)

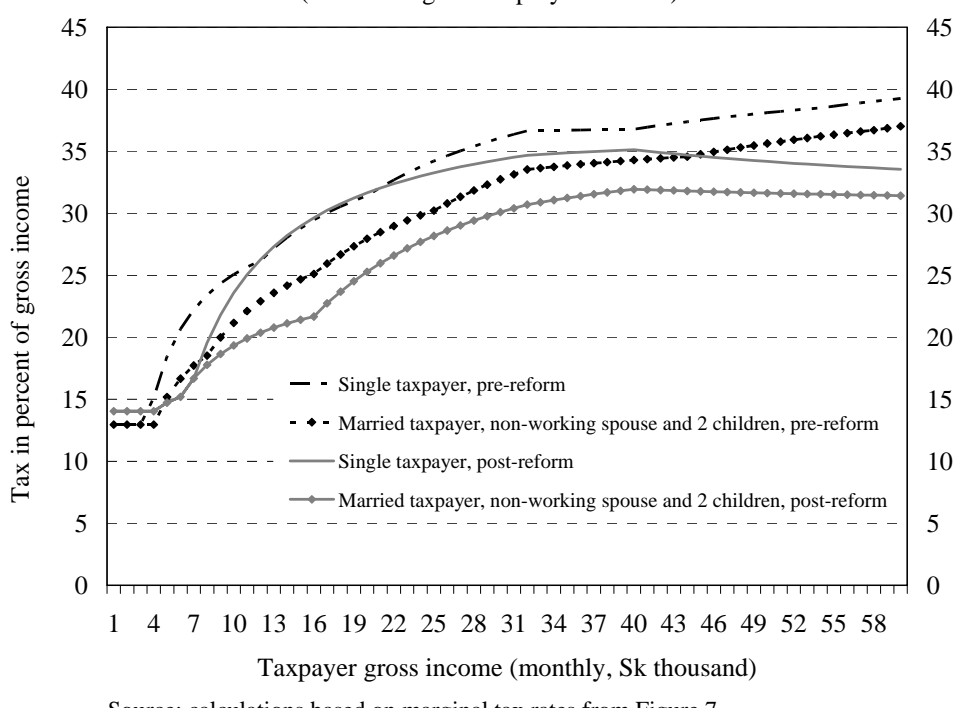

Source: calculations based on marginal tax rates from Figure 7 
Figure 17. Average Composite Tax Rate, Excluding Non-Health SSCs

(Percent of gross employee income)

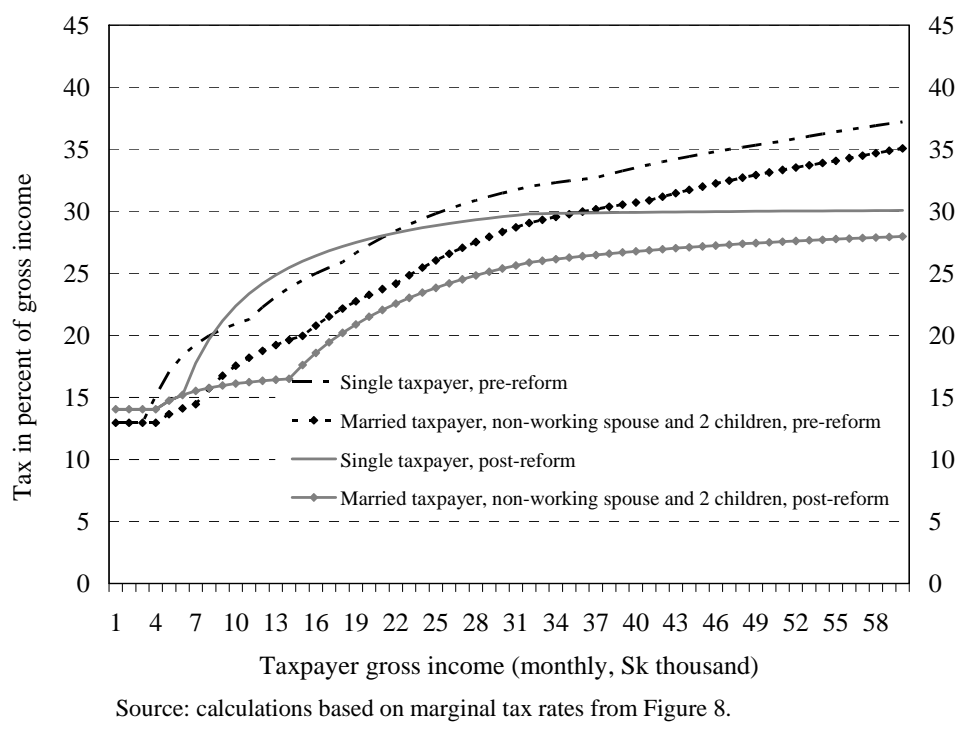

But distributional assessments including all social contributions could be biased if the corresponding benefits are not taken into account. Although payroll taxes may be very similar to income taxes in terms of the effects on behavior (and this is the treatment in the literature on tax wedges), it is not obvious that the distributional effects of income and payroll taxes are also similar. A ceiling on contributions may correspond to a ceiling on benefits that also should be taken into consideration. For example, Slovak public pension benefits have been traditionally very redistributive (IMF, 2002), and even with the strengthening of the benefit-contribution link under the new system, will remain subject to a ceiling. On the other hand, health contributions need not be matched to a particular set of benefits for an individual. Many countries finance public health expenditures through general taxation, rather than health insurance contributions. Figure 17 shows the average composite tax rate including health contributions, but excluding other social contributions. Including only this narrow subset of social contributions implies that the overall tax burden becomes proportional at higher income ranges, and that the system remains mildly progressive overall.

\section{Social Protection}

Section IV argued that the welfare reforms have corrected strong disincentives to work, but an important question remains whether the reformed safety net continues to provide adequate support. This paper can provide only partial answers on this question. The Slovak Ministry of Labor (2003b) notes that current national statistical sources do not fully meet Eurostat requirements for monitoring poverty and social exclusion and is developing new statistical instruments in line with Eurostat recommendations.

Previous studies found the pre-reform social assistance system to be effective at mitigating poverty. The World Bank (2001) Living Standards study found that the social transfer system alleviated poverty significantly. The study estimated on the basis of the 1996 Microcensus 
that canceling social transfers except for pensions would imply a poverty rate of 19 percent of all individuals, compared to an actual rate of 10 percent. For households whose main income earner is unemployed, canceling non-pension social transfers would imply a poverty rate of nearly 80 percent, compared to an actual poverty rate of 45 percent. Poverty risks may have since deteriorated: the Slovak Ministry of Labor (2004) estimates a risk-of-poverty rate of 28 percent before social transfers, and 21 percent after all social transfers. ${ }^{19}$

However, benefit dependency has contributed to the marginalization of some Roma communities, which are among the poorest in Slovakia. Roma are estimated to account for up to 10 percent of the Slovak population. Though some Roma are well integrated, others live in isolated settlements, in some cases with unemployment rates around 90 percent. The OECD (2002) estimates that Roma account for up to a fifth of overall unemployment in Slovakia. Thus, this group may be particularly strongly affected by the welfare reforms, especially since many have large families: implying both that they were particularly subject to poverty traps before the reforms, and that they face some of the largest benefit cuts as a result of the reforms. The Slovak Ministry of Labor (2003b) noted that the most recent hard data-from 1997-showed as many as 80 percent of Roma were dependent on social assistance benefits. The UNDP (2003) study of Roma in five central and eastern European countries found Roma unemployment rates around 70 percent in Slovakia, the highest of the five countries. The study found that these unemployment rates reflected not only weak labor market conditions, but also the "strong work disincentives that are built into the Slovak Republic's social welfare system".

For several years, welfare benefits have been below the "subsistence minimum". The subsistence minimum is a measure below which a household is considered to be in material need. The measure depends on family size, increasing by a flat amount per dependent child, and is uniform nationwide. It is indexed each July (Table 4). Although recent studies, including the OECD (2002), have noted the generosity of the social assistance scheme compared to average wages, social assistance benefits have been below the subsistence minimum since 2001 (Slovak Ministry of Labor, 2004).

\begin{tabular}{|lrr|}
\hline \multicolumn{3}{|c|}{ Table 4. The Subsistence Minimum } \\
\hline & July 2003 & July 2004 \\
\hline & Sk 4,210 & Sk 4,580 \\
One adult & Sk 2,940 & Sk 3,200 \\
plus second adult & Sk 1,910 & Sk 2,080 \\
plus dependent child & Sk 4,210 & Sk 4,580 \\
Example: & Sk 2,940 & Sk 3,200 \\
2 adults, 4 children & $4 \times$ Sk 1,910 & $4 \times$ Sk 2,080 \\
\cline { 2 - 3 } & Sk 14,790 & Sk 16,100 \\
\hline
\end{tabular}

19 In light of the data problems, this estimate should be treated with some caution. It is quite different from the estimate reported the previous year in the Slovak Ministry of Labor (2003b): a risk-of-poverty rate of 19 percent before social transfers, and 5 percent after all social transfers (compared to 40 percent and 15 percent respectively for the EU-15). 
The gap between the subsistence minimum and social assistance benefits has increased following the reforms, especially for families that do not participate in activation programs. The examples shown in Figure 3 assume one parent is employed and the other participates in activation programs; in these cases, the real benefit is unchanged at zero labor income only for the one-child family, and reduced for the other families. If neither parent is employed, the child tax bonus is not payable; and, without participation in activation programs, benefits are significantly lower. For families with five children, Slovak Ministry of Labor staff estimate typical benefit reductions of around 10-20 percent if parents participate in activation programs; if the parents do not participate, the benefit reductions - and the gap with the subsistence minimum-can exceed 50 percent.

The existence of a gap between the legal subsistence minimum and social assistance benefits is not clear evidence that benefits are necessarily inadequate. As noted, the subsistence minimum is uniform nationwide, but wages and living costs are generally higher in western Slovakia and lower in eastern regions where poverty is highest. Also, some of the gap between the benefit and the subsistence minimum may be filled by in-kind benefits, in particular for poor children who may receive free school meals. In cases where the child allowance is not paid to parents, for example due to child neglect or the child's failure to attend school, the municipality determines the most appropriate way to provide the child with the benefit.

\section{ConClusions}

With the tax and welfare reforms so recent, the conclusions to be drawn are a mixture of firm and tentative. Perhaps the clearest conclusion is that the tax reform has gained widespread attention from investors and policymakers alike, with several other countries looking to implement their own variants of the Slovak reform.

The fiscal implications of the reforms are not yet fully clear, but the initial evidence is encouraging. The tax reforms appear to have had a limited revenue cost, but more importantly, do not appear to have compromised the government's objectives of fiscal consolidation and reducing the fiscal deficit to Maastricht levels by 2007. But in light of the one-off effects of EU accession on indirect tax collections in 2004, data for 2005 will present a clearer picture of the permanent revenue effects of the reforms.

The tax and welfare reforms have reduced distortions in the economy and together have strengthened incentives to work and invest. The elimination of most exemptions contributes to better resource allocation and makes the tax system easier to administer-as does the single-rate VAT, which will help address long-standing problems with excessive VAT refunds. The tax reforms themselves may have only limited effects on work incentives, in view of the modest change in labor taxation for many taxpayers. But work incentives have been strengthened by the welfare reforms, through both the activation programs and lower marginal effective tax rates on incomes of welfare recipients. 
The tax system is less progressive than previously; whether it remains absolutely progressive depends on the assessment of social contributions. The flat-rate personal income tax includes large tax-free thresholds, ensuring the tax is progressive rather than proportional. Household spending data suggest that the single-rate VAT, and the higher excises, may have had only limited distributional effects. But the reform of social contributions was on a different track to the reform of state budget taxes, and social contributions-which are payable only up to a ceiling-remain a regressive component in the tax system. It is not obvious, though, whether social contributions should be treated simply as taxes, or whether they should be considered as being linked to future benefits.

Welfare reform has faced a difficult trade-off between addressing benefit dependency and risking deteriorating poverty. With ample evidence that the previous welfare system had promoted benefit dependency, reforms to curb dependency and encourage work effort were arguably necessary conditions for long-term reductions in poverty and unemployment. However, the short-run costs of the reforms may have been high for some of the poorest Slovak families, especially large families-particularly in regions where job opportunities have not been available to absorb newly willing labor supply. 


\section{REFERENCES}

Carone, Giuseppe, and Aino Salomäki, 2001, "Reforms in Tax-Benefit Systems in Order to Increase Employment Incentives in the EU," Economic Paper No. 160, DirectorateGeneral for Economics and Financial Affairs (Brussels: European Commission).

Choueiri, Nada, 2005, "Slovakia's Growth Potential and the Output Gap," in Slovak Republic: Selected Issues and Statistical Appendix, IMF Country Report No. 05/72, (Washington: International Monetary Fund).

Daveri, Francesco, and Guido Tabellini, 2000, "Unemployment, Growth and Taxation in Industrial Countries", Economic Policy: A European Forum, Vol. 30, pp. 47-101.

Disney, Richard, 2000, “The Impact of Tax and Welfare Policies on Employment and Unemployment in OECD Countries," IMF Working Paper WP/00/164 (Washington: International Monetary Fund).

European Commission, 2004, Structures of the Taxation Systems in the European Union, 1995-2002 (Luxembourg: Office for Official Publications of the European Communities).

Goliaš, Peter, 2004, "Fundamental Tax Reform in Slovakia," INEKO (Bratislava: Institute for Economic and Social Reforms), unpublished.

International Monetary Fund, 2002, "Pension Reform in the Slovak Republic," in Slovak Republic: Selected Issues and Statistical Appendix, IMF Country Report No. 02/210 (Washington: International Monetary Fund).

, 2005, Slovak Republic: Staff Report for the 2004 Article IV Consultation, IMF Country Report No. 05/71, (Washington: International Monetary Fund).

Ivanova, Anna, Michael Keen, and Alexander Klemm, 2005, “The Russian Flat Tax Reform," IMF Working Paper WP/05/16 (Washington: International Monetary Fund).

Moffitt, Robert A., and Mark Wilhelm, 1998, "Taxation and the Labor Supply: Decisions of the Affluent," NBER Working Paper 6621, (Cambridge, Massachusetts: National Bureau of Economic Research).

Nickell, Stephen, 1997, "Unemployment and Labor Market Rigidities: Europe versus North America," Journal of Economic Perspectives, Vol. 11. No. 3, pp. 55-74.

, 2004, "Employment and Taxes," CEP Discussion Paper No. 634 (London: Centre for Economic Performance, London School of Economics).

Norregaard, John, 1995, “The Progressivity of Personal Income Tax Systems," in Tax Policy Handbook, ed. by Parthasarathi Shome (Washington: International Monetary Fund). 
OECD, 1997, Making Work Pay: Taxation, Benefits, Employment and Unemployment (Paris: Organisation for Economic Co-operation and Development). , 2002, OECD Economic Surveys 2001-2002: Slovak Republic, Volume 2002/11, (Paris: Organisation for Economic Co-operation and Development). ,2003, "Benefits and Employment, Friend or Foe? Interactions Between Passive and Active Social Programmes," Chapter 4, OECD Employment Outlook (Paris: Organisation for Economic Co-operation and Development).

Slovak Ministry of Finance, 2003a, "Slovak Republic: Tax Reform Concept 2004-2006," (Bratislava) unpublished, available at http://www.finance.gov.sk ,2003b, "Fundamental Reform of the Slovak Tax System," in National Report on Economic Reform of the Product and Capital Markets (Cardiff Report) (Bratislava).

_ 2004, Convergence Programme for the Slovak Republic covering the period 20042010 (Bratislava).

Slovak Ministry of Labor, Social Affairs and Family, 2003a, Reform of the Pension System in the Slovak Republic (Bratislava).

, 2003b, with the European Commission, Joint Memorandum on Social Inclusion of the Slovak Republic (Brussels: European Commission).

,2004a, "The Reform of Assistance in Material Need," (Bratislava), unpublished. , 2004b, National Action Plan on Social Inclusion 2004-2006 (Bratislava).

Stepanyan, Vahram, 2003, "Reforming Tax Systems: Experience of the Baltics, Russia, and Other Countries of the Former Soviet Union," IMF Working Paper WP/03/173 (Washington: International Monetary Fund).

UNDP, 2003, Avoiding the Dependency Trap (New York: United Nations Development Programme), available at http://www.undp.sk

World Bank, 2001, Slovak Republic: Living Standards, Employment and Labor Market Study, Report No. 22351-SK, (Washington: World Bank). 


\section{SLOVAK REPUBLIC-BACKGROUND INFORMATION ON THE REFORMS}

\section{Tax Reform}

\section{Reform of State Budget Taxes}

The single-rate personal income tax replaces multiple tax rates according to level and type of income. According to the Slovak Ministry of Finance (2003b), the single 19 percent PIT rate replaces 21 different tax rates, including a five-band rate structure on labor income that ranged from 10 to 38 percent and withholding tax rates on capital income ranging from 5 to 25 percent. The reform also simplifies the definition of taxable income; Goliaš (2004) notes that the previous tax system included 443 classifications of income.

The tax-free threshold is now much higher. The reformed PIT includes a basic tax allowance (tax-free threshold) per taxpayer of Sk $80,832^{20}$ annually (previously Sk 38,760), plus a further Sk 80,832 spousal allowance (previously Sk 12,000). The reform also includes an annual tax credit of Sk 4,800 per child, which is part of the new child support system. (Figures 1 and 2 show the effective marginal income tax rate faced by an individual and a two-parent/two-children household before and after the reform.)

The corporate income tax has been lowered and dividend tax abolished. The 19 percent CIT rate is down from 25 percent in 2003, and compares to 40 percent in 1999. With the aim of taxing income only once, the reform also ends withholding tax on dividends, though taxes remained payable on dividends subsequently paid out of profits earned before 2004 .

Most income tax exemptions have been cancelled. Investment incentives have been scaled back: the reform cancels legislation providing for tax holidays (of up to 10 years) for newly established firms. ${ }^{21}$ Tax base reductions for certain sectors, such as agriculture and forestry, have been cancelled. The tax exemption on income from the sale of securities, held for 3 years or more, has also been cancelled.

Other CIT changes reduce the tax burden on businesses. The reform shortens the depreciation period on some groups of tangible assets, notably property and buildings, from 30 to 20 years. Loss carry-forward rules have been relaxed: losses can now be deducted from taxable income over the following 5 years, and annual write-off installments are no longer required to be equal. Also, limits on the tax deductibility of advertising and of vehicle depreciation have been cancelled.

20 The law sets the threshold at "19.2 times the monthly minimum subsistence" (equivalent to 1.6 times the poverty-line income), implying automatic indexation.

${ }^{21}$ However, the government may still individually grant investment incentives, in compliance with the EU law on state aid. 
The VAT rate has been unified at 19 percent and harmonized with EU law. The previous dual VAT rates had recently been brought closer, from a main rate of 23 percent and reduced rate of 10 percent in 2002, to 20 percent and 14 percent respectively in 2003 . The reduced rate had applied to a wide range of items, including food, electricity and thermal energy, heating oil, coal, pharmaceutical products, and aids for disabled persons. The EU's Sixth Directive on VAT permits a reduced rate only on a narrower range of distributionally sensitive items, and so the introduction of the single VAT rate brings Slovakia into compliance. Slovakia has reduced its annual turnover threshold for VAT registration from Sk 3 million (equivalent to just over $€ 70,000$ ) to Sk 1.5 million (just over $€ 35,000$ ), but has a permanent derogation from the Sixth Directive requirement of only $€ 5,000$.

Excise taxes are also being increased to harmonize with EU requirements. The excise increases were implemented already in August 2003, being brought forward to address an expected revenue shortfall in 2003. Taxes on motor fuels were increased from Sk 12.4/L to Sk 15.5/L; taxes on beer increased from Sk $30 /{ }^{\circ} \mathrm{Plato} / \mathrm{hL}$ to $\mathrm{Sk} 50 /{ }^{\circ} \mathrm{Plato} / \mathrm{hL}$; and taxes on tobacco products were also increased significantly, for cigarettes from Sk 0.95 per cigarette to Sk $1.40 .^{22}$ Further increases in tobacco excises will be necessary to fully harmonize with EU requirements; Slovakia has agreed to phase in these increases by 2007.

Some other smaller taxes were abolished. Inheritance and gift taxes, which together raised Sk 0.2 billion in 2003, were abolished from 2004. The real estate transfer tax, which raised Sk 2.4 billion in 2003, was cut from 6 percent to 3 percent effective January 2004, and abolished from 2005.

Further changes to the tax system from 2005 reflect the decentralization process, which aims to give municipalities a more predictable revenue stream and to strengthen their revenueraising powers:

- PIT is now subject to revenue-sharing. A recently approved package of decentralization laws provides that from 2005, 70.3 percent of PIT will go to municipalities, 23.5 percent to the eight regional self-governments ("VUCs"), and 6.2 percent to the central government. The shared PIT replaces a direct discretionary transfer from the state budget.

- The decentralization laws define 12 local taxes and one local fee, which municipalities are free to set themselves; central-government ceilings no longer apply to these taxes. The most important of these taxes are the road tax and real estate (ownership) tax.

22 Upon EU accession, this specific excise was converted to an equivalent excise with both specific and ad valorem components. 


\section{Social Contributions}

Contribution rates were reduced modestly in 2004. Changes to social contributions were implemented separately from the reform of state budget taxes. Effective from 2004, overall payroll taxes fell by 2.4 percentage points, with a small rise in employee contributions0.6 percentage points, for pension contributions - being offset by a 3 percentage point cut in employer contributions for sickness and unemployment insurance (Table A1).

Ceilings on contributions have also been reformed. Through 2003, each type of contribution was subject to a monthly "maximum assessment base" of Sk 32,000; that is, there was a ceiling on contributions equivalent to slightly more than twice the economy-wide average wage. In 2004, health insurance contributions remained subject to the Sk 32,000 maximum, but for most other social contributions, including pensions, the ceiling was raised to three times the average wage. Following the recent passage of health reform, the maximum assessment base for health insurance contributions will rise to Sk 43,095 from January 2005.

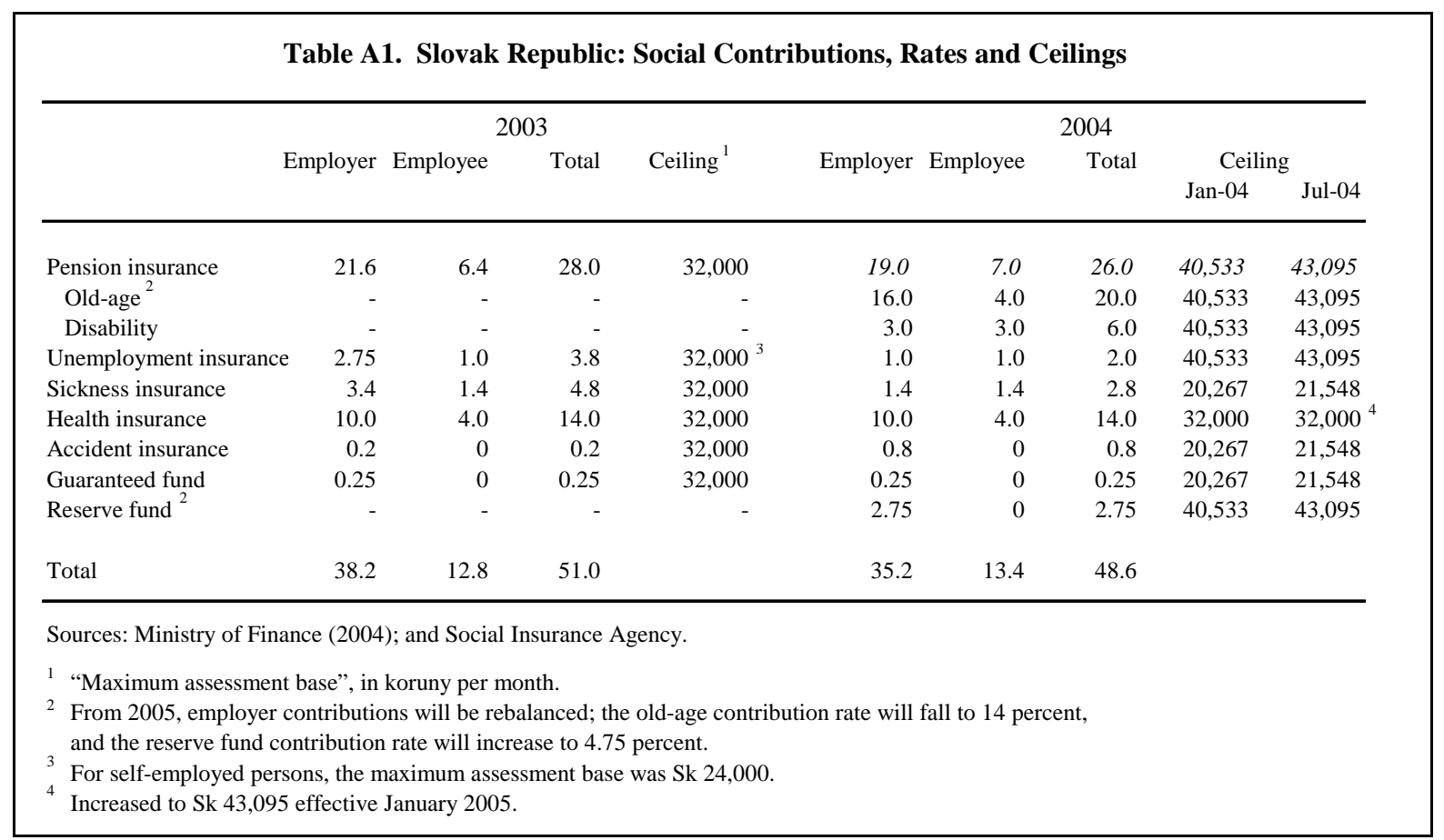

\section{Welfare Reform}

In 2003, initial reforms included a benefit ceiling and administrative measures to curb abuse of benefits. The government introduced a ceiling on monthly benefits per family of Sk 10,500; this was binding only for large families (six or more dependent children). Administrative measures included stricter enforcement of eligibility requirements, including requiring recipients to appear in person to collect benefits. 
The centerpiece of the 2004 reform was the introduction of an "activation program" by restructuring the benefit formula to depend on work effort. The basic benefit was significantly reduced; for example, the basic monthly benefit of an individual was reduced in January 2004 from Sk 2,900 to Sk 1,450 (Table A2). On the other hand, the reform introduced an "activation allowance"-initially Sk 1,000, raised in April 2004 to Sk 1,500_ for which recipients are required to demonstrate effort to improve their situation, for example participation in community volunteer work or retraining programs. Unlike unemployment insurance (see below), the activation allowance is payable indefinitely. For individuals deemed unable to participate in activation programs, an equivalent "protective allowance" is paid instead.

Participation in activation programs increased steadily through 2004. Most activation programs are organized by municipalities. Following shortages in early 2004, the Ministry of Labor has worked with municipalities to increase the number of available activation positions. Municipalities and NGOs are not required to pay wages to activated persons; they receive Sk 400 monthly for each activated person. The Ministry of Labor reports just over 100,000 individuals participated in activation programs by October 2004, compared with 56,000 in April. As at October, over 90,000 beneficiaries were participating in communitybased services organized by municipalities; just under 4,000 were undertaking further education or retraining.

Social assistance benefits are now reduced less abruptly if the recipient earns labor income. The previous social assistance scheme was a simple top-up of income to the benefit level; any additional earnings resulted in a correspondingly lower benefit. In the new scheme, several types of income are deemed exempt income in the calculation of the social assistance benefit, including 25 percent of individual income from dependent services.

The reform also changes the structure of supplementary child support. In addition to the basic social assistance benefit, the previous system included means-tested child bonuses (starting at Sk 270 per child, rising to Sk 890, depending on household income and the age of the child). The new system replaces these with a flat Sk 500 child bonus_-conditional on the child being enrolled in school ${ }^{23}$ — plus a Sk 400 tax credit. The Sk 500 child bonus is universal. In contrast, the tax credit is payable only to households in which at least one parent is employed, though it is refunded if the overall tax liability is negative (for example, a parent employed on minimum wage).

23 If the child is not enrolled in school, the bonus is paid to the relevant municipality, which is then required to decide on the best way to use it to benefit the child, for example through in-kind transfers. 
Table A2. The Monthly Social Assistance Benefit

\begin{tabular}{|c|c|c|c|c|}
\hline \multicolumn{2}{|c|}{ Previous system: to December 2003} & New system & Jan 2004 & Current $^{2}$ \\
\hline \multicolumn{2}{|c|}{ Income top-off, material need for "subjective reasons" 1} & \multicolumn{3}{|l|}{ Basic benefit } \\
\hline Individual & Sk 1,450 & Single person & Sk 1,450 & Sk 1,530 \\
\hline \multirow{2}{*}{\multicolumn{2}{|c|}{ Income top-off, material need for "objective reasons" 1}} & Individual parent with up to 4 children & Sk 2,160 & Sk 2,450 \\
\hline & & Individual parent with more than 4 children & Sk 3,160 & Sk 3,640 \\
\hline Dependent minor child & Sk 1,000 & Couple without children & Sk 2,530 & Sk 2,660 \\
\hline \multirow{7}{*}{ Maximum per family } & Sk 1,600 & Parents with up to 4 children & Sk 3,210 & Sk 3,630 \\
\hline & Sk 10,500 & Parents with more than 4 children & Sk 4,210 & Sk 4,850 \\
\hline & & Pregnancy allowance ${ }^{3}$ & Sk 350 & Sk 350 \\
\hline & & Activation allowance / protection allowance & Sk 1,000 & Sk 1,500 \\
\hline & & Housing bonus: 1-person household & Sk 780 & Sk 780 \\
\hline & & Housing bonus: multiple-person household & Sk 1,330 & Sk 1,330 \\
\hline & & Healthcare allowance, per person & Sk 50 & Sk 50 \\
\hline
\end{tabular}

Source: Based on information provided by the Slovak Ministry of Labor, Social Affairs and Family.

1 The previous system distinguished between material need for "objective" and "subjective" reasons. "Objective" reasons included involuntary unemployment and inability to find work despite search efforts. "Subjective" reasons included an individual voluntarily leaving a job or refusing a job offer. Material need was usually deemed to be for "subjective" reasons for households in the system for more than 24 months.

2 The activation allowance was increased in April 2004. Basic benefits were indexed in September 2004.

${ }^{3}$ Paid only to a single person or couple without children. 


\section{Other Benefit Reforms}

Although this paper focuses on the reforms to the tax and welfare systems, unemployment benefits and the pension system also have implications for work incentives. The major labor market concern in Slovakia is long-term unemployment, which accounts for roughly twothirds of the total unemployment rate of nearly 18 percent. Slovak unemployment insurance benefits are payable only in the short-term and have played a much more limited role than the welfare system in sustaining unemployment. The World Bank (2001) found that those receiving unemployment benefits tend to spend longer unemployed periods compared to those not receiving unemployment benefits, but look for work more actively than nonrecipients, and find private-sector jobs more often. Nonetheless, recent reforms to unemployment benefits and to the pension system should also contribute to stronger incentives to work.

\section{Unemployment Insurance}

Eligibility periods have been cut and the benefit more closely linked to past contributions. An unemployed person is eligible for benefits for up to 6 months, compared to 9 months until end-2003. The beneficiary must have contributed for 24 of the previous 36 months to be eligible. The replacement rate is 50 percent of past gross income; previously, this had been 55 percent for the first 6 months, falling to 45 percent for the last 3 months. Benefits remain subject to a ceiling, now being raised: the ceiling had been around half the economy-wide average wage and was raised to 60 percent of the average wage in 2004 . The ceiling will increase further in 2005 and 2006.

\section{Sickness Benefits}

Responsibilities have been shifted from the public to the private sector. From 2004, the responsibility for paying the first 10 days of sickness benefits has been shifted from the public sector (via the Social Insurance Agency) to individual employers. This measure has not only lowered costs to the public sector (though offset by a reduction in the sickness insurance contribution rate), but also gives employers much stronger incentives to verify that sickness claims are genuine.

\section{Pension Benefits}

The pension reform approved in 2003 reforms the existing public pension system, and introduces a mandatory, privately funded pillar. ${ }^{24}$ The reform of the public pay-as-you-go system provides for a gradual increase in retirement ages to 62 years for both men and women, from 60 (men) and 57 or less (women); and a closer link between future benefits and contributions. The first increase in retirement ages was effective from January 2004. The new privately funded (second) pillar started operations in January 2005.

\footnotetext{
${ }^{24}$ For a detailed overview of the pension reform, see Slovak Ministry of Labor (2003a).
} 